DEMOGRAPHIC RESEARCH

VOLUME 38, ARTICLE 37, PAGES 1059-1110 PUBLISHED 21 MARCH 2018

http://www.demographic-research.org/Volumes/Vol38/51/

DOI: 10.4054/DemRes.2018.38.51

Research Article

\title{
The positive impact of women's employment on divorce: Context, selection, or anticipation?
}

\section{Daniele Vignoli} Anna Matysiak

\section{Marta Styrc}

Valentina Tocchioni

This publication is part of the Special Collection on "The New Roles of Women and Men and Implications for Families and Societies," organized by Guest Editors Livia Sz. Oláh, Rudolf Richter, and Irena E. Kotowska.

\section{(C) 2018 Daniele Vignoli et al.}

This open-access work is published under the terms of the Creative Commons Attribution 3.0 Germany (CC BY 3.0 DE), which permits use, reproduction, and distribution in any medium, provided the original author(s) and source are given credit.

See https://creativecommons.org/licenses/by/3.0/de/legalcode. 


\section{Contents}

1 Introduction $\quad 1060$

$2 \quad$ Women's employment and divorce 1061

$2.1 \quad$ Theoretical perspectives and empirical evidence 1061

$\begin{array}{lll}2.2 & \text { The country context } & 1062\end{array}$

2.3 Unobserved factors 1064

$\begin{array}{lll}2.4 & \text { Anticipation mechanisms } & 1064\end{array}$

$3 \quad$ Country contexts $\quad 1064$

$3.1 \quad$ Women's employment 1064

3.2 Reconciliation policies and gender norms 1066

$\begin{array}{lll}3.3 & \text { State support for single mothers } & 1067\end{array}$

$3.4 \quad$ The economic necessity of a second income 1067

$\begin{array}{lll}3.5 & \text { The democratization of divorce } & 1068\end{array}$

$3.6 \quad$ Research hypotheses 1069

$4 \quad$ Analytical strategy $\quad 1070$

5 Data 1073

$6 \quad$ Empirical findings $\quad 1074$

$6.1 \quad$ Selection effects $\quad 1074$

6.2 Impact of women's employment on divorce 1075

$\begin{array}{lll}6.3 & \text { Anticipation effects } & 1076\end{array}$

$\begin{array}{llr}7 & \text { Conclusions } & 1078\end{array}$

$8 \quad$ Acknowledgements $\quad 1081$

$\begin{array}{lr}\text { References } & 1082\end{array}$

$\begin{array}{lr}\text { Appendix } & 1089\end{array}$ 


\title{
The positive impact of women's employment on divorce: Context, selection, or anticipation?
}

\author{
Daniele Vignoli $^{1}$ \\ Anna Matysiak ${ }^{2,3}$ \\ Marta Styrc ${ }^{3}$ \\ Valentina Tocchioni ${ }^{4}$
}

\begin{abstract}
BACKGROUND

Empirical findings regarding the impact of women's employment on divorce are mixed. One explanation is that the effects are moderated by the country context. Another is that previous studies have failed to account for unobserved factors that introduce bias into the estimated effects. Studies also rarely consider possible anticipatory employment behavior on the part of women who are thinking of divorce.
\end{abstract}

\section{OBJECTIVE}

The aim of this study is to deepen our understanding of the nexus between women's employment and divorce in a comparative perspective.

\section{METHODS}

We adopt an analytical strategy that allows us to account for selection and anticipation mechanisms. Namely, we estimate marital disruption and employment jointly, and monitor the timing of divorce after employment entry. This approach is implemented using micro-level data for Germany, Hungary, Italy, and Poland.

\section{RESULTS}

We find that women's employment facilitates marital disruption in Italy and Poland, but not in Germany and Hungary. We also show that selection effects play out differently in different contexts. Finally, we notice traces of anticipatory behavior in Italy.

\footnotetext{
${ }^{1}$ University of Florence, Italy. Email: daniele.vignoli@unifi.it.

${ }^{2}$ Wittgenstein Centre (IIASA, VID/ÖAW, WU), Vienna Institute of Demography, Austrian Academy of Sciences, Vienna, Austria.

${ }^{3}$ Institute of Statistics and Demography, Warsaw School of Economics, Poland.

${ }^{4}$ University of Florence, Italy.
} 


\section{CONTRIBUTION}

We conclude that women's employment is less likely to be linked to divorce in countries with easier access to divorce and in countries with more generous financial support for families and single mothers, which in turn makes women less reliant on the market. With this study we hope to encourage future researchers to consider the potentially distorting effects of selection and anticipation strategies in (comparative) divorce research.

\section{Introduction}

Women's labor force participation has been increasing across all industrialized economies for at least half a century. Over the same period, rates of marital dissolution have also risen. In response to these trends, social observers have become increasingly interested in the effects of women's social and economic independence on divorce. ${ }^{5} \mathrm{~A}$ first line of research, based upon the dominant male breadwinner/female carer economic model of the family, has hypothesized that women's employment represents a potent force that is driving divorce rates up (see Hobson 1990; Kalmijn and Poortman 2006; Ruggles 1997; Schoen et al. 2002). A second line of research has challenged this assertion: It has been argued that men's and women's social roles have been changing (Cooke 2004; Sayer and Bianchi 2000; Sigle-Rushton 2010), and that woman's earnings can stabilize a marriage by contributing to the family budget (Cherlin 2000; Oppenheimer 1997; Stevenson and Wolfers 2007).

Empirical findings on these questions are mixed. One possible explanation for this heterogeneous pattern is that the effects of women's economic resources on the risk of divorce are moderated by the country context in which women make life-changing decisions about work and marriage (e.g., Cooke et al. 2013; van Damme and Kalmijn 2014; Kaplan and Stier 2010; Styrc and Matysiak 2012). Another explanation lies in individual-level characteristics, often unobserved by researchers, which may simultaneously affect a woman's employment and the stability of her marriage; for example, her level of attachment to family values, her career orientation, or her psychological traits. A failure to account for these characteristics may bias the estimated effect of women's employment on divorce. Finally, previous studies rarely took into account the possibility that a woman who has become dissatisfied with her marriage might intensify her efforts in the labor market in anticipation of a divorce (e.g., Poortman 2005; van Damme and Kalmijn 2014). Studies that do not account for

5 In the following, we use the terms 'divorce,' 'marriage disruption,' and 'marriage dissolution' interchangeably. 
this anticipation mechanism may overestimate the positive effect of women's employment on divorce risk.

The goal of this paper is to deepen our understanding of the nexus between women's employment and marital instability. We analyze marriage disruption because marriage represents a union context that can be more easily compared across different countries than cohabitation. Cohabitation has different meanings in different countries (Perelli-Harris et al. 2014), and is less coherently acknowledged in different policy areas (Perelli-Harris and Sánchez Gassen 2012). Our contribution is threefold. First, we compare countries that differ in terms of their institutional, cultural, and economic settings; we do so to investigate how specific country contexts shape the relationship between women's employment and marital stability. Second, we wash out possible biases from the presence of unobserved time-constant factors: We do this through the simultaneous modeling of women's employment and partnership biographies within a common maximum likelihood event-history framework. Third, we monitor the possibility of a woman's anticipatory entry into the labor market prior to a divorce by looking at how the effect of women's employment on divorce changes once she has entered employment.

To implement our innovative analytical strategy we use harmonized data from the Generations and Gender Survey (GGS), selecting countries with samples that are large enough to offer robust and stable estimates at the country level, namely, Germany, Hungary, Italy, and Poland. These countries differ in several dimensions: norms regarding women's employment and parenthood, policies supporting the economically weaker party in case of a divorce, the degree to which having a second income is an economic necessity, and divorce diffusion. These differences enabled us to formulate country-specific expectations about the impact of women's employment on marital stability.

\section{Women's employment and divorce}

\subsection{Theoretical perspectives and empirical evidence}

Several theoretical arguments predict a positive relationship between women's employment and divorce. The economic model of marriage proposed by Becker, Landes, and Michael (1977) presupposes that the woman's entry into the labor market will lower a couple's gains from specialization, and will therefore increase tension within the marriage (see also Becker 1981). Others argue that the labor-market involvement of both partners may lead to a status competition between husband and wife (Parsons 1940; Raz-Yurovich 2012) or might be indicative of a husband's poor 
performance as an income provider (Cherlin 1979; Jalovaara 2003), which might lead to strains within the couple. Given that employment gives a woman the resources necessary for ending an unhappy marriage (the so-called independence hypothesis, see Hobson 1990; Ruggles 1997; Schoen et al. 2002), her entry into employment may increase the divorce risk.

These arguments have been criticized for relying on a traditional model of the gendered division of labor. More recently it has been suggested that economic contributions to the household budget by both partners improve a couple's living standard and allow them to be better prepared for a job loss on the part of one of the two (Cherlin 2000; Härkönen 2013; Oppenheimer 1997; Raz-Yurovich 2012; Sayer and Bianchi 2000; Stevenson and Wolfers 2007). Furthermore, similarity of activities and interests allows partners to share their skills, knowledge, and networks (Coltrane 2000; Sayer and Bianchi 2000; Simpson and England 1981), enhancing the quality of the marriage (Bernardi 1999; Blossfeld and Drobnic 2001; Özcan and Breen 2012).

The research findings on the effect of women's employment on divorce are as ambiguous as the theoretical predictions (Lyngstad and Jalovaara 2010). We posit that there are at least three reasons for this. First, the opposing theoretical arguments about the effect of woman's employment on marital stability are derived from contrasting assumptions about women's role in the family. Theories that predict a positive association between women's employment and divorce rely on the assumption that women are the main care providers, and thus women's entry into the labor market will lead to strains between the partners. By contrast, theories that anticipate a negative relationship assume that both partners work for pay and that they divide domestic and care work. Whether empirical studies find a positive or negative association between women's employment and divorce may thus depend on the country context; e.g., on the extent to which the traditional division of labor is supported by family policies, social norms dominant in the country, or a country's economic condition. Furthermore, empirical findings might be inconsistent due to methodological shortcomings in previous studies. Past research has rarely considered the unobserved characteristics of women, which jointly affect women's employment and divorce decisions and which confound the observed relationship between the two variables. Meanwhile, researchers have often failed to account for the fact that women may enter employment to be in a better position to get divorced.

\subsection{The country context}

The literature has identified five major context dimensions that can affect the divorce risks of employed and nonemployed women: norms about men's and women's social 
roles (Blossfeld and Müller 2002; Cooke et al. 2013), work-family reconciliation policies (Blossfeld and Müller 2002; Cooke 2006; Cooke et al. 2013; Cooke and Gash 2010), financial support for single parents (van Damme, Kalmijn, and Uunk 2009; Kaplan and Stier 2010), the level of men's earnings relative to family maintenance costs (e.g., Cherlin 2000; Oppenheimer 1994, 1997; Stevenson and Wolfers 2007), and the diffusion of divorce in a given society (Goode 1993; Härkönen and Dronkers 2006; Matysiak, Styrc, and Vignoli 2014).

The normative expectations about men's and women's social roles define which roles men and women should and should not take. In more traditional contexts, where women are considered to be mainly responsible for domestic tasks and men for providing income, women's participation in the labor market may lead to more conflict and lower satisfaction in a marriage than in egalitarian societies (Carlson et al. 2016). Women may also receive less support from their male partners in combining paid work and care than in egalitarian societies, and this may further increase women's dissatisfaction with their partner.

The lack of public policies for working parents (such as high-quality, accessible childcare) may further increase the conflict between paid work and care experienced by working women, and thus intensify work-family tensions (Neyer 2003; Cooke et al. 2013). Therefore, we might expect stronger marital strains and consequently higher divorce risks in countries where paid work and childrearing lacks institutional and cultural support.

The link between women's employment and marital stability may also be moderated by government support for single parents. Having access to special forms of financial assistance or childcare arrangements for single parents weakens a woman's dependence on her partner and on the market (Kaplan and Stier 2010).

In addition, in countries where the man's earnings are often insufficient for household expenses, the financial contribution of a wife may stabilize a marriage; whereas this is not necessarily the case in countries where a woman's income is less crucial to the household budget (Oppenheimer 1997; Stevenson and Wolfers 2007).

Finally, in countries where divorce was or still is a relatively rare event, marital disruption is associated with high social and economic costs. Women with more resources - e.g., with a job or with a higher level of education - may find it easier to get divorced than women with fewer resources (Goode 1993; Härkönen and Dronkers 2006). When divorce becomes more common in a given society the differentials in women's ability to bear the economic and social costs of divorce fade away, and the positive association between woman's employment and divorce risk weakens (Matysiak, Styrc, and Vignoli 2014). 


\subsection{Unobserved factors}

The second explanation for inconsistent empirical findings may be related to the inability of researchers to control for women's characteristics that jointly affect women's employment and marriage choices. They may encompass attachment to family, career orientation, gender role attitudes, and psychological traits that determine personal success in various life domains. Data on such characteristics is rarely available and a failure to account for them leads to an estimation bias (see also van Damme and Kalmijn 2014). The positive effect of women's employment on divorce risks can, for example, be overestimated if the women display a high propensity to enter employment and dissolve a union for unobserved reasons (positive selection); e.g., because they have a strong career orientation and a low level of attachment to family values. On the other side, the positive impact of women's employment on divorce can be underestimated if the women have a high propensity to exit employment or exit a marriage for unobserved reasons (negative selection) such as poor health or a 'risktaking' personality.

\subsection{Anticipation mechanisms}

Yet another reason why the findings concerning the relationship between women's employment and divorce have been inconsistent is that these studies relied on the observed order of events (e.g., employment entry and divorce). As such, they took for granted that the divorce decision and the actual divorce happen at the same time. Such a strategy biases the effect of women's employment on divorce risk upwards if married women increase their involvement in the labor market in response to a decline in their satisfaction with marriage and a fear of marriage disruption (van Damme and Kalmijn 2014; Oppenheimer 1997; Özcan and Breen 2012). Empirical studies have provided some evidence for such anticipatory adjustments, though these adjustments do not seem to be strong (Austen 2004; Johnson and Skinner 1986; Papps 2006; Poortman 2005; Rogers 1999).

\section{Country contexts}

\subsection{Women's employment}

Women in Hungary and Poland became integrated into the labor market in the second half of the $20^{\text {th }}$ century and are currently much better established as income providers 
than women in Germany and Italy (Figure 1$).{ }^{6}$ In the early 1970s the labor force participation rate of women of prime working age (25-54) was 78\% in Poland and $66 \%$ and growing in Hungary. Even though the collapse of state socialism in the early 1990s led to labor market turmoil and resulted in a strong decline in employment, in both countries more than $70 \%$ of women remained in the labor force. In West Germany and Italy, labor force participation in the early 1970 s was much lower (less than $50 \%$ in West Germany and less than $30 \%$ in Italy) but has been steadily growing since, especially in Germany.

Figure 1: Labor force participation of women aged 25-54. Germany, Hungary, Italy, Poland, 1970-2011

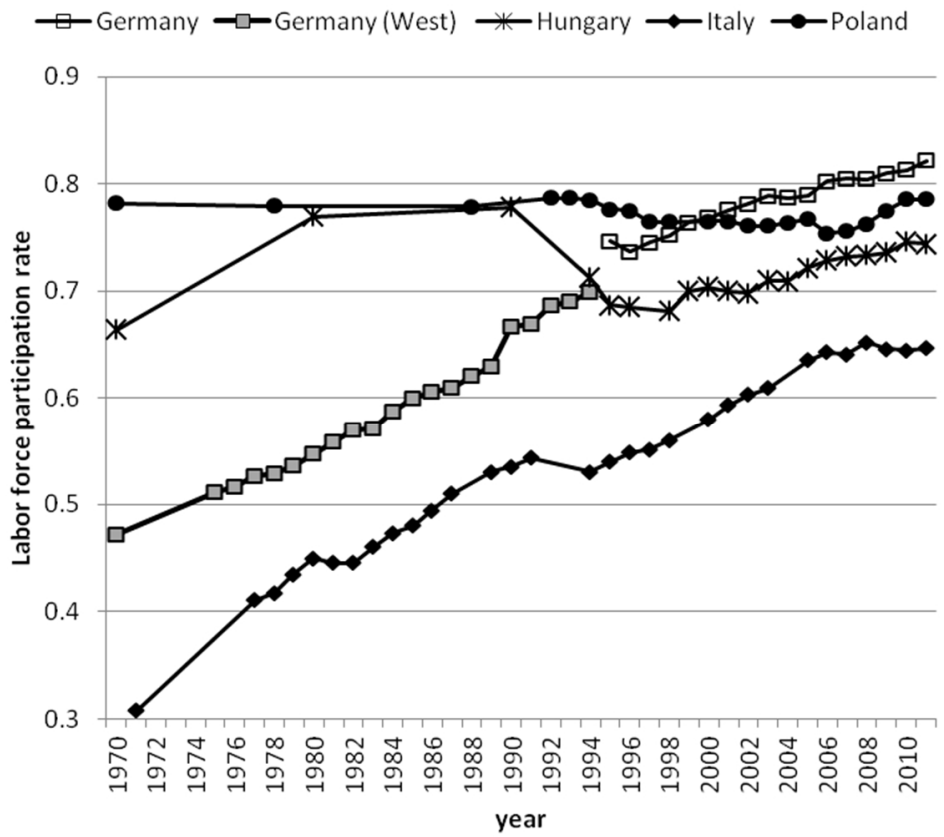

Source: Own elaboration based on ILO LABORSTA (up to 2008) and Eurostat data (2009-2011). Note: For Italy, the 1977-1980 rate is for women aged $25-49$.

${ }^{6}$ Germany unified in 1990 from two states that had previously had distinct economic and legal arrangements. The process of unification was accomplished mostly through the incorporation of the former GDR into the political, legal, and economic system of the FRG. This is the main reason why our description focuses on the FRG. The second reason is that the population of the FRG was more numerous than the population of the GDR; hence, the observations referring to the geographical boundaries of the current Germany before 1990 are dominated by the FRG. 
Vignoli et al:: The positive impact of women's employment on divorce: Context, selection, or anticipation?

\subsection{Reconciliation policies and gender norms}

None of the four countries provides good conditions for the reconciliation of paid work and family life (Matysiak and Węziak-Białowolska 2016). Public support for parents who want to combine paid work and family is weak and the social acceptance of mothers' employment is relatively low. Nonetheless, there are some differences across countries.

Under state socialism, Poland and Hungary adopted the dual-earner/femaledouble-burden model. Women were expected to provide both income and care, while men were free from providing care and domestic chores. Women combined work and family obligations supported by employment protection laws and childcare services (Fodor et al. 2002; Pascall and Manning 2000). After Poland and Hungary transitioned to a market economy both countries sharply reduced family-related expenditures. Family policy in Hungary remained more generous than in Poland, though it is difficult to say whether it was more supportive of working parents. On the one hand, the supply of childcare services in the 1990s and 2000s was better in Hungary than in Poland (Szelewa 2012; Szikra and Szelewa 2010). On the other hand, Hungary provided more generous family benefits and parental-leave payments, which was shown to slow down mothers' return to work after birth (Matysiak and Szalma 2014). Despite the changes in public support for combining paid work and care, the social expectations for women and men have remained unchanged: Women continue to be perceived as the main care providers, and they are also expected to work for pay (Pascall and Manning 2000). This situation, in which women receive little support from the state and from their partners but where they need to work and take primary responsibility for household and childcare, leads to serious work-family tensions, especially in Poland.

In Germany the welfare system was designed to support the traditional division of labor. This meant poor childcare provision, high part-time employment of mothers, and income tax splitting, favoring traditional male breadwinner families (Ostner 1993). Women were primarily expected to provide care, i.e., to stay at home with very young children and work only part-time when children were at school (Treas and Widmer 2000). Since the 1990s, however, Germany has been gradually expanding its public childcare services and in 2007 reformed its parental leave system, offering clear incentives for men to spend more time with children (Evers, Lewis, and Riedel 2005; Rosenfeld, Trappe, and Gornick 2004). The reform resulted in an increase in men's participation in childcare (Geisler and Kreyenfeld 2012) and coincided with an increase in the social acceptance of working women (Unterhofer and Wrohlich 2017).

Italian family policies are the least supportive of gender equality. Even though the country has experienced a strong increase in female labor market participation in the last decades (Vignoli, Drefahl, and De Santis 2012), public services remain limited for children aged zero-three and the levels of male participation in domestic chores 
continue to be very low (Anxo et al. 2011; Vignoli 2013). Furthermore, leave for newborns is short: a mandatory leave of five months for mothers, which can be extended by six months, and an option of six months leave for fathers, which is rarely used. In addition, compensation is low (30\% of salary). Finally, social acceptance of women's employment and an egalitarian division of labor also remains low in Italy (Matysiak and Węziak-Białowolska 2016; Treas and Widmer 2000).

\subsection{State support for single mothers}

In all four countries, single mothers receive some financial support from the state. Depending on the country, this support comes in the form of family benefits, social assistance, tax breaks, or social benefits in kind (e.g., housing benefits). Of the four countries, however, Italy is the only one that offers financial support for single mothers that is conditional on employment: Nonworking single mothers in Italy do not receive any financial support from the state. In the remaining countries, support for single mothers is means-tested and falls with women's earnings, with the steepest declines observed in Poland. Public support for nonworking single mothers is most generous in Germany: $43 \%$ of the average national wage, compared to around $30 \%$ in Hungary and Poland (own computation based on OECD 2008; available upon request). However, as single mothers in Germany, Hungary, and Poland take up employment, state support falls. For instance, the income of a single mother who earns the average national wage is topped up by some $14 \%$ in Germany and Hungary. Due to strong means testing, no social support is granted to single mothers in Poland at this pay level.

Forms of alimony, such as child support payments from a nonresident parent, usually represent the second kind of financial support single parents are entitled to receive. The share of sole parents receiving child support from the nonresident parent is highest in Germany and Hungary at nearly 34\%, is slightly lower in Poland at nearly $31 \%$, and is lowest in Italy at $22 \%$ (OECD 2011).

\subsection{The economic necessity of a second income}

The four countries studied also differ greatly in terms of affluence, which determines the extent to which the economic activity of both partners is required for a household's needs. Here we examine the percentages of household expenditure spent on 'basic' goods, a category that encompasses food and non-alcoholic beverages; housing, including water, electricity, gas, and other fuels; and clothing and footwear. Our computations, based on Eurostat data from 2005 and 2010 and available on request, 
show that households in Germany spend the least on basic consumption expenditure (proportional to their total expenditure), followed by Hungary and Italy. The need for the second income seems to be highest in Poland, where basic consumption expenditure constitutes the highest proportion of total household expenditure. ${ }^{7}$ Consistent with these findings, Klesment and Van Bavel (2017) find that women in the postsocialist European countries contribute higher proportions of income to the household budgets than women in other European countries.

\subsection{The democratization of divorce}

The four countries also differ in terms of the diffusion of divorce. As shown in Figure 2, divorce has long been commonplace in Hungary and Germany, and both countries currently have relatively high divorce levels: More than $40 \%$ of marriages are expected to dissolve if the current duration-specific divorce rates hold. ${ }^{8}$ Poland had rather stable levels of marital dissolution throughout the 1970s and the 1980s, but divorce rates in the country have rocketed since the mid-late 1990s. In Italy the marked increase in marital disruption began after 1980 and accelerated in the 2000s. ${ }^{9}$ The higher levels of divorce in Hungary and Germany suggest that in those countries divorce is less selective than in Italy and Poland, where the incidence of marital dissolution is lower.

\footnotetext{
${ }^{7}$ Basic consumption expenditure as a proportion of total household expenditure for households with one working person and households with two working persons amount to 0.46 and 0.43 in Germany, 0.54 and 0.5 in Hungary, 0.56 and 0.51 in Italy and 0.61 and 0.57 in Poland.

${ }^{8}$ The sharp fall in divorces at the end of the $1970 \mathrm{~s}$ is due to the introduction of the new divorce laws in the former Federal Republic, which made the legal procedure leading to a divorce longer. See: http://www.bibdemografie.de/EN/Facts_Figures/Divorces/Figures/a_05_06_zusgef_ehescheidungsziffer_d_w_o_ab1970.ht $\mathrm{ml}$.

${ }^{9}$ It is important to note that the total divorce rate is not the best indicator for describing patterns of union dissolution in Italy, as it downplays the phenomenon. Due to the fact that until 2015 the normative process toward marital dissolution included a period of 'separation' regulated by law, the total separation rate long illustrated elevated levels of marital disruption. For instance, in 2014 the total separation rate amounted to 319 separations per 1,000 marriages, while the total divorce rate stopped at 183 divorces per 1,000 marriages (Istat 2016).
} 
Figure 2: Trends in the total divorce rate in Germany, Hungary, Italy, and Poland, 1970-2011

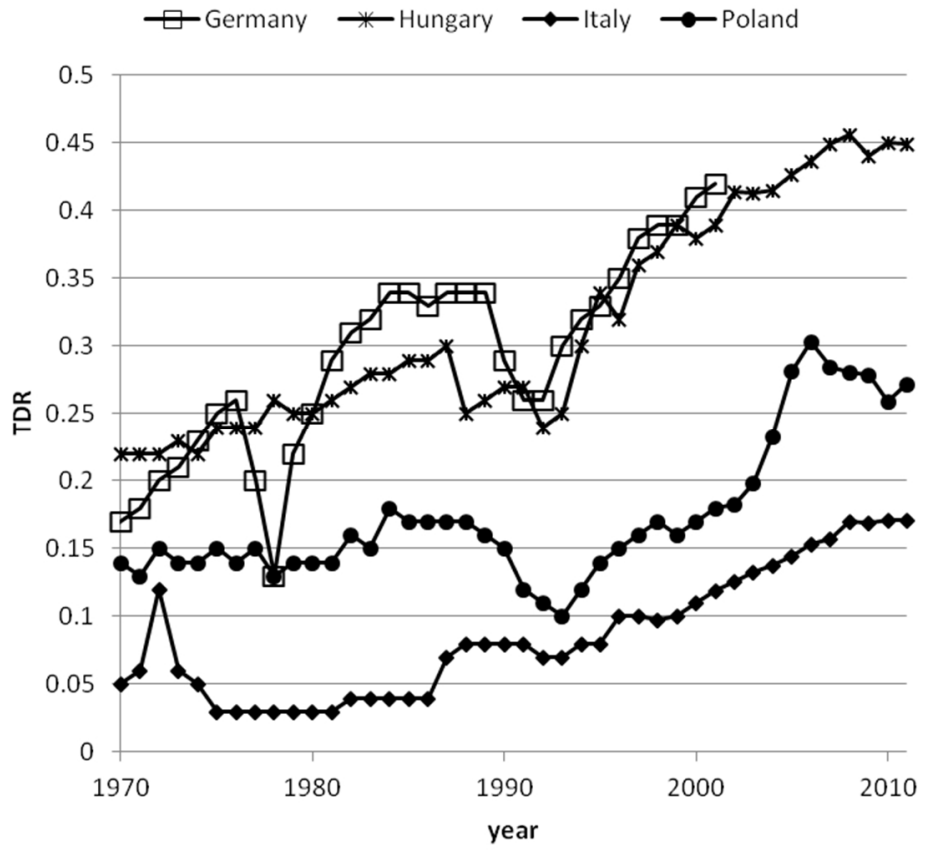

Source: Council of Europe Data up to 2004; own calculations on Eurostat data for 2005-2011.

\subsection{Research hypotheses}

We expect to find that the association between woman's employment and any divorce risk will differ depending on the contextual setting of each country. We anticipate that it will be strongly positive in Italy. This country has only weakly rooted economic activities for women, a strongly anchored male breadwinner model, unfavorable conditions for work-family reconciliation, and only very limited support for single mothers. Conditioning financial support for single mothers on employment status in Italy may also be a strong driver of mothers taking up work if they expect union dissolution. Thus, it is likely that an anticipation mechanism contributes to the positive effect of employment.

Hungary and Poland have high levels of women's employment that are historically rooted. In these countries a dual-earner family model is a prerequisite for satisfying the 
economic needs of family members and financial assistance for single mothers is more generous than in Italy. Nonetheless, support for combining paid work and care is relatively weak in these countries. Thus, we might expect the positive association between woman's employment and divorce risk to be weaker than in Italy. Furthermore, there might also be differences between Hungary and Poland in the impact of women's employment on divorce, though it would be difficult to establish the direction of this difference. Hungary has more generous state support for single mothers and divorce is more widespread and thus less selective of certain socioeconomic groups. All this would suggest that the association between woman's employment and divorce is weaker in Hungary than in Poland. On the other hand, the economic needs of Polish households seem to be greater, and thus women's employment may have a more stabilizing effect on marriages in Poland.

Germany is characterized by high levels of women's labor force participation, but the current levels are the result of intensive growth since the 1970s. Many women still go part-time after becoming mothers and often do not return to full-time employment until their children enter school, although this has been changing in recent years. Germany is also characterized by generous support for single mothers and high levels of divorce, which should weaken the positive effects of women's employment on marriage dissolution. On the other hand, women's employment is less necessary to cover household expenditure in Germany than in the other three countries. Consequently, we expect to find that the impact of woman's employment on divorce in Germany is positive but rather weak, as in Hungary.

\section{Analytical strategy}

In order to address our research objectives we have developed an analytical model that allows us to account for women's selection and anticipation strategies. First, we present a multi-process hazard model, which accounts for individual time-constant unobservables. Second, we extend the model by adding conditional splines of time since employment entry to the equation (1) to account for anticipation.

Our multi-process hazard model consists of three single-process hazard models estimated jointly (the subscripts for an individual were suppressed for the sake of simplicity):

$$
\begin{aligned}
& \ln h^{D}(t)=\alpha_{0}+\alpha_{1} \operatorname{DurMar}(t)+\alpha_{2} Z^{D}(t)+\alpha_{3} X^{D}+\alpha_{4} E m p(t)+\varepsilon^{D} \\
& \ln h^{E N}(t)=\gamma_{0}+\gamma_{1} \operatorname{DurNonE}(t)+\gamma_{2} Z^{E N}(t)+\gamma_{3} X^{E N}+\varepsilon^{E N}
\end{aligned}
$$




$$
\ln h^{E X}(t)=\delta_{0}+\delta_{1} \operatorname{DurE}(t)+\delta_{2} Z^{E X}(t)+\delta_{3} X^{E X}+\varepsilon^{E X}
$$

where $h^{D}(t)$ constitutes the hazard of marriage disruption, $h^{E N}(t)$ the hazard of employment entry, and $h^{E X}(t)$ the hazard of employment exit, with time t measured in months. The baseline log hazards are modeled with the use of piecewise linear spline functions of time (for more details see Lillard 1993).

The process time in equation (1) is the time elapsed since marriage formation until its disruption (settled at the date of the de facto separation), the death of a partner, or the time of the interview - whichever occurred first $(\operatorname{DurMar}(t))$. Our main explanatory variable is a binary indicator of woman's employment status, $\operatorname{Emp}(t)$, and a woman was classified as being employed if she was either working or was on maternity or parental leave. We controlled for a series of time-constant $X^{D}$ and time-varying $Z^{D}(t)$ covariates. Finally, equation (1) contains a random term $\varepsilon^{D}$, which is fixed over a woman's lifetime. It is assumed to follow a normal distribution with a zero mean and a standard deviation $\sigma_{\varepsilon} D$, and describes a woman's unobserved time-invariant proneness to dissolve a marriage.

Overall, our main interest is the estimate of the effect of a woman's employment on her marriage disruption risk; i.e., in parameter $\alpha_{4}$. However, this parameter might be biased due to a possible selection of divorce-prone individuals in the employed/ nonemployed pool according to unobserved woman-specific characteristics. In order to account for the selection, we need to estimate equation (1) jointly with equations (2) and (3) in a common maximum likelihood framework (see Lillard, Brien, and Waite 1995; Lillard and Panis 1996). The identification of the model is attained through within-person replication (Lillard, Brien, and Waite 1995: 446). Note that such an approach only accounts for time-constant unobserved characteristics that are derived from 'serial' behavior over the life course - in this specific context, women who have had more than one divorce and several employment episodes.

Equations (2) and (3) model the transitions, respectively, to and out of employment. In equation (2) a woman is observed from age fifteen until her first entry into employment, and later when she exits a job until she enters another one. Likewise, in equation (3) a woman is followed from her first entry into a job until her exit from that job, and later from the point at which she starts a second or subsequent job until she exits that job. The variables DurNonE(t) and $\operatorname{DurE}(t)$ represent the baseline hazards; i.e., the time since entering nonemployment and employment, respectively. They are assumed to shift proportionally by a series of time-constant $X$ and time-varying $Z(t)$ covariates. Both equations also contain woman-specific unobserved heterogeneity terms, $\varepsilon^{E N}$ and $\varepsilon^{E X}$, which are assumed to be normally distributed (with respectively zero means and standard deviations $\sigma_{\varepsilon^{E N}}$ and $\sigma_{\varepsilon^{E X}}$ ) and represent woman-specific, timeconstant, unobserved propensity terms for entering and exiting employment. 
The simultaneous estimation of equations (1)-(3) implies that the woman-specific unobserved heterogeneity terms are jointly distributed:

$$
\left(\begin{array}{c}
\varepsilon^{\mathrm{D}} \\
\varepsilon^{\mathrm{EN}} \\
\varepsilon^{\mathrm{EX}}
\end{array}\right) \sim \mathrm{N}\left(\left(\begin{array}{l}
0 \\
0 \\
0
\end{array}\right),\left(\begin{array}{ccc}
\sigma_{\varepsilon^{D}}^{2} & \rho_{\varepsilon^{D} \varepsilon^{E N}} & \rho_{\varepsilon^{D} \varepsilon^{E X}} \\
& \sigma_{\varepsilon^{E N}}^{2} & \rho_{\varepsilon^{E N} \varepsilon^{E X}} \\
& & \sigma_{\varepsilon^{E X}}^{2}
\end{array}\right)\right)
$$

A positive correlation between the unobserved propensity of women to divorce and enter employment $\left(\rho_{\varepsilon^{D} \varepsilon^{E N}}>0\right)$ and a negative correlation between the unobserved propensity of women to divorce and exit employment $\left(\rho_{\varepsilon^{D} \varepsilon^{E X}}<0\right)$ are signs of the selection of divorce-prone women into the employed pool due to time-constant unobserved characteristics. Conversely, a negative correlation between the unobserved propensity of women to divorce and enter employment $\left(\rho_{\varepsilon^{D} \varepsilon^{E N}}<0\right)$ and a positive correlation between the unobserved propensity of women to divorce and exit employment $\left(\rho_{\varepsilon^{D} \varepsilon^{E X}}>0\right)$ implies that divorce-prone women select themselves for the nonemployed pool.

This model specification does not, however, account for any possible adjustments in a woman's labor market status in anticipation of a divorce, which biases upward the estimated effect of women's employment on divorce risk. In order to account for such adjustments, in the next step we replace the binary variable describing a woman's employment status with a conditional spline for the time since her entry into employment (see also Kulu and Vikat 2007). The spline switches on at employment entry, and allows us to verify whether and how the risk of marriage disruption changes over time after a woman has entered employment. There are three possibilities here. First, if the risk of divorce increases markedly after employment entry and continues to increase, we can attribute the divorce to increasing tension between partners resulting from the woman's entry into the labor market (causation). Second, if the risk of divorce increases sharply after employment entry and remains elevated and constant from then on, we can conclude that the positive impact of women's employment on divorce is not due to anticipation behavior (causation). Finally, symptoms of anticipatory adjustments can be detected if the risk of divorce increases abruptly after employment entry and starts to decline after a relatively short period, when the women who entered employment in response to an upcoming divorce separate from their husbands. 


\section{Data}

We used data from the GGS for Germany, Hungary, and Poland and from the Multipurpose Household Survey "Family and Social Subjects" (FSS) for Italy. For Germany and Hungary we used the first two waves of the GGS, which were carried out in 2004-2005 and 2008-2009 for both countries. We did so because the employment history of each respondent was only recorded in the second wave. The Italian FSS, conducted in 2009, was intended to replicate the 2003 Italian GGS. For Poland we used the first wave of the GGS, which was carried out at the turn of 2010 and 2011 and which already contained employment history. The overall response rates were 55\% (first wave) and 50\% (second wave) for the German GGS, $83 \%$ for both waves of the Hungarian GGS, 55\% for the Polish GGS, and 81\% for the Italian FSS. From these datasets we extracted married women who were born in 1955 or later (Table 1).

We considered quite a few potential confounders when estimating the effects in question. The complete set of time-constant and time-varying controls is listed in the Table A-1 (Appendix). It is also important to know other factors such as women's religiosity or urban versus rural area of residence. However, in GGS surveys these are only collected at the time of the interview, and their inclusion in the models introduces the risk of performing an "anticipatory analysis" (Hoem and Kreyenfeld 2006a, 2006b). Being a retrospective survey, GGS data does not include information on ex-partners. This means that we cannot include the male partner's characteristics in the estimation equation.

Table 1: Analytical sample: Overall samples and subsamples of first and higher-order marriages, Germany, Hungary, Italy, and Poland

\begin{tabular}{lclc}
\hline & Overall sample & $\begin{array}{l}\text { Women who entered } \\
\text { first marriage }\end{array}$ & Second and higher-order marriage \\
\hline Germany & 1,340 & 1,038 & 61 \\
Hungary & 2,938 & 2,222 & 171 \\
Italy & 10,586 & 6,709 & 143 \\
Poland & 6,352 & 4,731 & 135 \\
\hline
\end{tabular}

We are aware that it would have been important to distinguish between East and West Germany in the analysis. However, the German GGS only provides us with information on the place of residence at the time of the interview. Given the massive east-to-west migration after the fall of the communist system, we could not use this information retrospectively. 


\section{Empirical findings}

Our modeling strategy consisted of three steps. First, we estimated the single-process hazard models of marriage disruption, entry into employment, and exit from employment (M1) (namely, equations (1)-(3) modeled separately). Second, we estimated the multi-process hazard model, which means that we allowed the unobserved person-specific characteristics to correlate across equations (M2). Third, the explanatory variable in the regression equation of marital disruption indicating woman's employment in model M2 was replaced by a conditional piecewise linear spline from entry into employment (M3). By comparing the results obtained in the first and second step we assess to what extent the link between employment and divorce is affected by the selection. By comparing the results obtained in the second and third steps we evaluate whether the estimated effect of employment on marital instability results from a woman's anticipatory behavior. Full model outcomes are available in Tables A-2-A-13 (Appendix).

\subsection{Selection effects}

The estimates of the parameters of the unobserved heterogeneity terms from the multiprocess model M2 are reported in Table 2. The significant estimates of the residuals' standard deviations indicate that there is considerable variability in the person-specific unmeasured characteristics in all of the processes under consideration in Hungary, Italy, and Poland. Few of the correlations between the unobserved heterogeneity terms turned out to be significant. This means that we were quite successful in selecting the covariates that control for important antecedents of divorce and employment processes, both of which influence the two processes. Nonetheless, some correlations between unobserved heterogeneity terms are shown to be significant. For example, we found that in Poland the unobserved heterogeneity term of marital disruption correlates positively with the unobserved heterogeneity term of employment exit. This finding implies that women with an above-average unobserved propensity to terminate employment also have an above-average propensity for marital break-up. Thus, in Poland the estimate of the impact of women's employment on marital disruption, derived from a standard single-process model M1, provides us with downwardly biased estimates. 
Table 2: Unobserved heterogeneity terms from regressions of divorce, entry into employment, and exit from employment: standard deviations and correlations. Germany, Hungary, Italy, and Poland

\begin{tabular}{|c|c|c|c|c|c|c|c|c|c|c|}
\hline & $\begin{array}{l}\text { Germany } \\
\text { estimate }\end{array}$ & SE & $\begin{array}{l}\text { Hungary } \\
\text { estimate }\end{array}$ & \multirow[t]{2}{*}{ SE } & \multicolumn{2}{|c|}{$\begin{array}{l}\text { Italy } \\
\text { estimate }\end{array}$} & \multirow[t]{2}{*}{ SE } & \multicolumn{2}{|c|}{$\begin{array}{l}\text { Poland } \\
\text { estimate }\end{array}$} & \multirow[t]{2}{*}{ SE } \\
\hline \multicolumn{8}{|c|}{ Standard deviations of unobserved heterogeneity terms } & & & \\
\hline Marital disruption & 0.86 & 0.64 & 0.60 * & 0.34 & 0.83 & ** & 0.40 & 0.81 & *** & 0.30 \\
\hline Employment entry & 1.10 & 0.07 & $0.69^{* * *}$ & 0.03 & 0.91 & $* * *$ & 0.03 & 0.87 & *** & 0.03 \\
\hline Employment exit & 1.01 & 0.14 & $0.62^{* * *}$ & 0.06 & 0.77 & *** & 0.04 & 1.08 & $* * *$ & 0.06 \\
\hline \multicolumn{11}{|c|}{ Correlations between unobserved heterogeneity terms } \\
\hline $\begin{array}{l}\text { Marital disruption and } \\
\text { employment entry }\end{array}$ & 0.51 & 0.31 & 0.01 & 0.13 & 0.14 & & 0.10 & 0.13 & & 0.10 \\
\hline $\begin{array}{l}\text { Marital disruption and } \\
\text { employment exit }\end{array}$ & 0.12 & 0.23 & 0.17 & 0.18 & 0.04 & & 0.10 & 0.41 & $* \star \star$ & 0.15 \\
\hline Employment entry and exit & -0.43 & 0.11 & -0.03 & 0.09 & 0.21 & 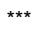 & 0.06 & -0.01 & & 0.05 \\
\hline
\end{tabular}

Note: ${ }^{*}$ significant at $10 \%$; ${ }^{* \star}$ significant at $5 \%$; ${ }^{* \star *}$ significant at $1 \%$.

\subsection{Impact of women's employment on divorce}

The single-process hazard models yield positive effects of employment on marital disruption in all countries but Hungary, where the impact is insignificant (Table 3, M1). The magnitude of the effect appears to be strongest in Italy, where employed women have a $50 \%$ higher risk of marital disruption than nonemployed women. The risk of divorce for women in employment is $35 \%$ higher than for nonemployed women in Germany and 20\% higher in Poland. After the correlation between processes is allowed for, the positive effect of employment remains significant only in Italy and Poland (Table 3, M2).

In Germany the previous positive effect of women's employment on divorce risks (obtained in M1) becomes insignificant in M2. This is so even though the correlations between unobserved heterogeneity terms in the processes for divorce and employment entry/employment exit are insignificant. Nonetheless, the size of the correlation between the unobserved heterogeneity terms in the processes of divorce and employment entry is quite large (see Table 2), and its nonsignificance might be attributable to the scarcity of within-person replications (i.e., second and higher-order divorces). Hence, a positive selection seems to emerge in Germany: Women with weak family orientation are also strongly work-oriented. In Italy, the positive impact of women's employment on divorce decreases from 1.49 to 1.38 . This reduction is in line with the positive correlation between the unobserved heterogeneity terms for marital disruption and entry into employment. It suggests the selection of divorce-prone women into the pool of the employed due to unobserved time-constant characteristics. This 
correlation term, whose size is not negligible (0.14), is, however, not significant; this might be due, again, to the low number of repeated events. In Poland, meanwhile, the positive effect of women's employment on divorce intensifies from over $20 \%$ to over $40 \%$ after we account for the correlation between employment and union disruption processes. This change is in line with the results presented in Table 2. These show that women who are more likely to quit employment are also, for unobserved reasons, more likely to divorce.

Table 3: Relative risks of the effect of women's employment on divorce. Estimates from single-process and multi-process hazard models. Germany, Hungary, Italy, and Poland

\begin{tabular}{|c|c|c|}
\hline & Single-process model (M1) & Multi-process model (M2) \\
\hline \multicolumn{3}{|c|}{ Indicator of being employed (ref. = not employed) } \\
\hline Germany & $1.35 *$ & 1.11 \\
\hline Hungary & 1.14 & 1.16 \\
\hline Italy & 1.49 & 1.38 \\
\hline Poland & 1.22 & 1.42 \\
\hline
\end{tabular}

Note: * significant at $10 \%$; ${ }^{* \star}$ significant at $5 \%$; ${ }^{* \star *}$ significant at $1 \%$. Estimates are controlled for duration of marriage, age at first marriage, marriage order, calendar time, number of children, age of the youngest child, educational level, parental divorce, parental education, cohabitation prior to first marriage, conception/birth prior to first marriage.

\subsection{Anticipation effects}

Finally, we investigated how the risk of marital disruption is related to time since entry into employment (M3). The results of the spline estimate are presented in Figure 3. In Germany and Hungary the risk of marital disruption increases only slightly after employment entry, and remains insignificant thereafter. This confirms our findings that women's employment does not affect marital disruption in those two countries. In Poland the risk of marital disruption increases strongly after a woman's entry into employment, and remains at that level thereafter. This suggests that marital disruption in Poland is positively related to women's employment in general, but there are no signs of anticipatory behavior. Finally, in Italy we found that the risk of marital disruption increases strongly after a woman enters employment, then decreases with time. This decline in the risk of marital disruption suggests that some women entered employment because they feared their union might dissolve. This finding points to the presence of anticipatory adjustments in Italy, suggesting that the positive effect of women's employment on divorce seen in Table 3 is partly driven by anticipation. Nevertheless, it appears that anticipatory behavior does not explain the overall effect of employment on marital stability in Italy, as the positive relationship between the two 
processes is still observed several years after a woman has entered employment. Even ten years after employment entry her risk of divorce is more than $20 \%$ higher than that of a nonemployed woman.

Figure 3: Duration-dependent effect of employment on divorce, estimates from a multi-process hazard model with time since employment entry in equation (1) (Model M3). Germany, Hungary, Italy, and Poland
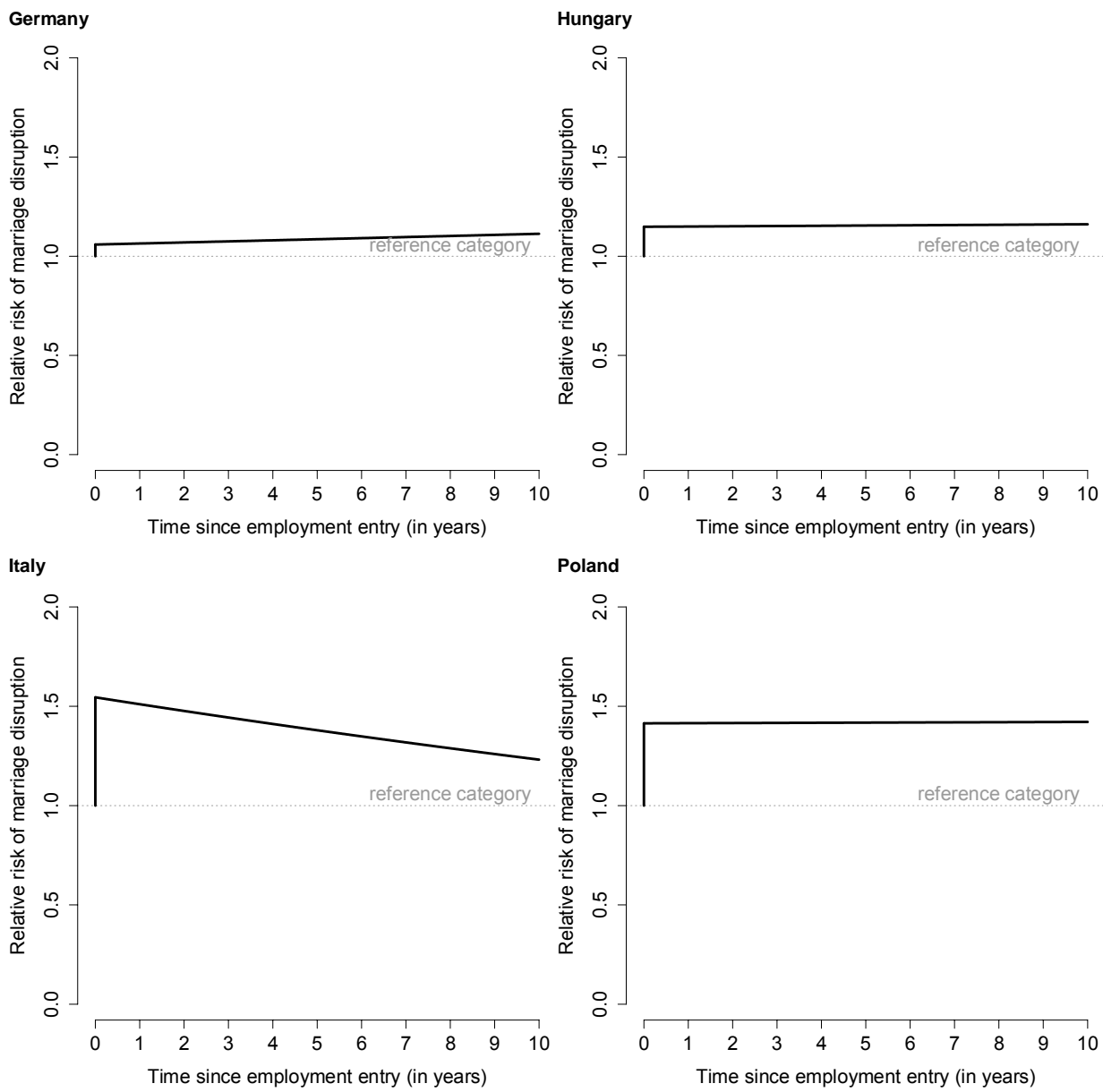

Note: Estimates are controlled for duration of marriage, age at first marriage, marriage order, calendar time, number of children, age of the youngest child, educational level, parental divorce, parental education, cohabitation prior to first marriage, conception/birth prior to first marriage. 
Vignoli et al:: The positive impact of women's employment on divorce: Context, selection, or anticipation?

\section{Conclusions}

In this study we investigated the impact of women's employment on divorce in Germany, Hungary, Italy, and Poland using a novel solution that accounted for two potentially interfering elements: first, estimation bias due to women's unobserved characteristics, which may jointly affect the two processes; and, second, the anticipatory employment behavior of women who might expect to divorce in the near future.

Our findings show that women's employment has a strongly positive effect on marital disruption in Italy and Poland, and no effect in Germany and Hungary. Today, Italy is still dominated by male breadwinners, unfavorable conditions for work-family reconciliation, and relatively low female employment rates. In Poland, the dual earner family model is much more prevalent than in Italy, but the country continues to be characterized by a traditional division of unpaid work within couples, and women's employment is not sufficiently supported by public policies (Matysiak and Vignoli 2013). State support for single mothers is weak in Poland and rudimentary in Italy. The elevated divorce risks of employed women in Italy and Poland are thus in line with traditional microeconomic perspectives. Finally, they are largely consistent with previous research on the two countries (Liefbroer and Dourleijn 2006; De Rose 1992; Salvini and Vignoli 2011; Styrc and Matysiak 2012; Vignoli and Ferro 2009), even though these studies did not consider selection and anticipation mechanisms.

By contrast, in contemporary Hungary and Germany the impact of women's employment on divorce appears to be negligible. Despite Hungary's shared legacy with Poland, we found no significant impact of women's employment on divorce for Hungary. The effect of women's employment on divorce is not detectable in the country for a number of reasons. In Hungary, the (full-time) dual-earner family model has been dominant for over 50 years. But, in contrast to Poland, Hungary places less economic pressure on women to be economically active after divorce because of the country's relatively generous financial transfers to families and single mothers. What is more, the incidence of divorce is quite high. These results are in line with previous empirical evidence for Hungary (e.g., Liefbroer and Dourleijn 2006; Oláh 2001). Like Hungary, Germany, where we found no significant effects of women's employment on marital disruption, displays relatively high levels of divorce and, again, relatively generous support for single mothers.

Overall, the first key result of our study is that there is country variation in the impact of women's employment on divorce even after accounting for selection and anticipation mechanisms. Women's employment is less likely to be linked to divorce in Germany and Hungary - i.e., in countries with easier access to divorce, where women from all social strata are more likely to be able to afford a divorce. Likewise, women's employment is less likely to be linked to divorce in countries with more generous 
financial support for families and single mothers, which lessen women's reliance on the labor market.

The second important contribution of our article is that we showed that the correlation between employment and marital instability can be affected by selection mechanisms. The multi-process specification changed the findings for Germany and Poland and confirmed those for Hungary and Italy. In Germany the slightly significant higher risk of marital disruption for employed women vanished in the multi-process variant of the model. Hence, the impact of women's employment on divorce in Germany is partly driven by selection effects; e.g., by women who have a weak family orientation or a low-quality marriage, or who are strongly work-oriented or successful in the labor market. This may explain why previous studies on the topic generated conflicting messages for Germany - e.g., Cooke (2006) and Cooke et al. (2013) showed that the two processes are not significantly related; Liefbroer and Dourleijn (2006) found a significantly positive association between women's employment and union disruption in West Germany, and no significant relationship in East Germany; van Damme and Kalmijn (2014) illustrated a positive association for both East and West Germany. The same multi-process specification for Poland yielded estimates that were negatively biased due to the selection of divorce-prone women who were not in employment. This finding suggests that in Poland unobserved factors simultaneously affect the propensity to exit employment and the propensity to exit a marriage. Such behavior may be reinforced by the structure of financial support available to single mothers. Poland is fairly generous to nonworking or low-paid single mothers, but financial assistance is not provided to single mothers with average or higher earnings.

The third key finding is related to the question of whether the positive correlation between employment and divorce results from the wife's attempt to secure her own source of income in anticipation of marital disruption. Similarly to Poortman (2005), we found little evidence for anticipatory behaviors. Italy was the only country where some traces of anticipation were found. This is likely attributable to the still low women's labor force participation there. A woman facing a high risk of marital disruption may take up a new labor market activity, as almost all of the state support available to single mothers is conditional on being employed (through tax breaks or family reconciliation policies like enhanced access to public childcare). Though we found a pattern of anticipation behavior in Italy, it is worth noting that this pattern does not fully explain the elevated levels of disruption risk for employed women, as these levels remained high even several years after entry into employment.

Our study has its limitations. First, for data-related reasons we focused on only four countries. Although we cover a wide range of different arrangements for women's participation in private and public life, it would have been interesting to include a country where the conditions for reconciling paid work and family life are good, where 
gender equality in the public and private spheres is high, and where the state support for single mothers is more generous. We hope that our research strategy will be applied to these kinds of contexts when suitable data is available. Second, as the surveys we used do not include information on ex-partners, we were unable to look at couples in the analysis; thus, we could control only for the respondent's information in predicting divorce risk. It has, however, been suggested that information on both partners' contributions to paid and unpaid work are needed to properly assess the impact of women's employment on union dissolution (Mencarini and Vignoli 2017; Oláh and Gähler 2014; Sigle-Rushton 2010). Third, it is possible to argue that group-specific differences matter: For instance, selection and anticipation mechanisms may play an even larger role among younger cohorts, in more recent time periods, or among certain social classes. Due to the sample's limitations - we had a limited number of marriages and divorces of second and higher orders - we could not explore these possibilities using our data because of model convergence failures. Fourth, controlling for women's time-constant unobserved characteristics is a substantial improvement over the conventional event-history applications. However, our estimates may still be biased by selection effects due to time-varying unmeasured factors, as women might change their attitude toward paid work and family life over their life course. Next, our method of controlling for anticipatory behavior does not take into account the possibility that women who are already employed may try harder to remain employed if they expect to divorce. If we could also account for anticipatory adjustments of this kind we might find signs of anticipatory behaviors in other countries with more widespread female employment than Italy. Finally, based on our findings we are not able to disentangle the mechanisms behind the positive effects of women's employment on divorce in Italy and Poland. This positive effect can be driven by tensions between partners that arise when both spouses spend a considerable amount of time outside the home, in particular if there are small children. In addition, employment may also give women resources to dissolve unhappy marriages that they would not otherwise have. It would be interesting to investigate in future research which of these mechanisms, if any, is responsible for our findings.

Our study has yielded new results for Germany, Hungary, Italy, and Poland that are both robust and coherent. We conclude that the country context is essential for filtering the impact of women's employment on divorce. We have shown that common unobserved antecedents influence both women's employment and divorce risks that induce selection mechanisms, and that these mechanisms may operate differently in different contexts. In addition, we found that women's anticipatory employment adjustments are country-specific. Removing these biases is crucial for generating valid and meaningful comparisons. Hence, with this study we hope to encourage future 
researchers to consider the potentially distorting effects of selection and of anticipation strategies, especially when different contextual settings are compared.

\section{Acknowledgements}

This study was conducted within the European Union's Seventh Framework Programme (FP7/2007-2013) under grant agreement no. 320116 for the research project "FamiliesAndSocieties" and from the Ministry of Science and High Education in Poland under grant agreement no. 2886/7.PR/2013/2 according to financial rules of cofinancing FP7 projects from partners' financial resources. The research was initiated within the project "New Family Patterns in Italy and Poland: Finding the Determinants of the Change (FAMCHIP)," (825N-WŁOCHY/2010/0) financed by the National Science Centre in Poland. Valentina Tocchioni and Daniele Vignoli also acknowledge the financial support provided by the research project "Families and Well-being in Italy: Dynamics and Relationships" [Famiglie e benessere in Italia: Dinamiche e relazioni], financed by the University of Florence (PI: Daniele Vignoli). Irena E. Kotowska, Rudolf Richter, and Elena Pirani are thanked for their comments on a preliminary version of the paper. 
Vignoli et al:: The positive impact of women's employment on divorce: Context, selection, or anticipation?

\section{References}

Anxo, D., Mencarini, L., Pailhé, A., Solaz, A., Tanturri, M.L., and Flood, L. (2011). Gender differences in time use over the life course in France, Italy, Sweden, and the US. Feminist Economics 17(3): 159-195. doi:10.1080/13545701.2011.582 822 .

Austen, S. (2004). Labour supply and the risk of divorce: An analysis of Australian data. Australian Economic Review 37(2): 153-165. doi:10.1111/j.1467-8462.20 04.00316.x.

Becker, G.S. (1981). A treatise on the family. Cambridge: Harvard University Press.

Becker, G.S., Landes, E.M., and Michael, R.T. (1977). An economic analysis of marital instability. Journal of Political Economy 85(6): 1141-1188. doi:10.1086/26 0631 .

Bernardi, F. (1999). Does the husband matter? Married women and employment in Italy. European Sociological Review 15(3): 285-300. doi:10.1093/oxford journals.esr.a018264.

Blossfeld, H.-P. and Drobnic, S. (2001). Careers of couples in contemporary society: From male breadwinner to dual-earner families. New York: Oxford University Press.

Blossfeld, H.-P. and Müller, R. (2002). Guest editors' introduction: Union disruption in comparative perspective: The role of assortative partner choice and careers of couples. International Journal of Sociology 32(4): 3-35. doi:10.1080/15579336. 2002.11770257.

Carlson, D.L., Miller, A.J., Sassler, S., and Hanson, S. (2016). The gendered division of housework and couples' sexual relationships: A reexamination. Journal of Marriage and Family 78(4): 975-995. doi:10.1111/jomf.12313.

Cherlin, A.J. (1979). Work life and marital dissolution. In: Levinger, G. and Moles, O.C. (eds.). Divorce and separation: Context, causes and consequences. New York: Basic Books: 151-166.

Cherlin, A.J. (2000). Toward a new home socioeconomics of union formation. In: Waite, L.J., Bachrach, C., Hindin, M., Thomson, E., and Thornton, A. (eds.). The ties that bind: Perspectives on marriage and cohabitation. New York: Aldine De Gruyter: 126-144. 
Coltrane, S. (2000). Research on household labor: Modeling and measuring the social embeddedness of routine family work. Journal of Marriage and Family 62(4): 1208-1233. doi:10.1111/j.1741-3737.2000.01208.x.

Cooke, L.P. (2004). The gendered division of labor and family outcomes in Germany. Journal of Marriage and Family 66(5): 1246-1259. doi:10.1111/j.0022-2445. 2004.00090.x.

Cooke, L.P. (2006). 'Doing' gender in context: Household bargaining and risk of divorce in Germany and the United States. American Journal of Sociology 112(2): 442-472. doi:10.1086/506417.

Cooke, L.P., Erola, J., Evertsson, M., Gähler, M., Härkönen, J., Hewitt, B., Jalovaara, M., Kan, M., Lyngstad, T.H., and Mencarini, L. (2013). Labor and love: Wives' employment and divorce risk in its socio-political context. Social Politics 20(4): 482-509. doi:10.1093/sp/jxt016.

Cooke, L.P. and Gash, V. (2010). Wives' part-time employment and marital stability in Great Britain, West Germany and the United States. Sociology 44(6): 10911108. doi:10.1177/0038038510381605.

De Rose, A. (1992). Socio-economic factors and family size as determinants of marital dissolution in Italy. European Sociological Review 8(1): 71-91. doi:10.1093/ oxfordjournals.esr.a036623.

Evers, A., Lewis, J., and Riedel, B. (2005). Developing child-care provision in England and Germany: Problems of governance. Journal of European Social Policy 15(3): 195-209. doi:10.1177/0958928705054082.

Fodor, E., Glass, C., Kawachi, J., and Popescu, L. (2002). Family policies and gender in Hungary, Poland, and Romania. Communist and Post-Communist Studies 35(4): 475-490. doi:10.1016/S0967-067X(02)00030-2.

Geisler, E. and Kreyenfeld, M. (2012). How policy matters: Germany's parental leave benefit reform and fathers' behavior 1999-2009. Rostock: Max Plank Institute for Demographic Research (MPIDR working paper 21).

Goode, W.J. (1993). World changes in divorce patterns. New Haven: Yale University Press.

Härkönen, J. (2013). Divorce: Trends, patterns, causes, consequences. Stockholm: Stockholm University (Stockholm Research Report in Demography 7). 
Vignoli et al.: The positive impact of women's employment on divorce: Context, selection, or anticipation?

Härkönen, J. and Dronkers, J. (2006). Stability and change in the educational gradient of divorce: A comparison of seventeen countries. European Sociological Review 22(5): 501-517. doi:10.1093/esr/jcl011.

Hobson, B. (1990). No exit, no voice: Women's economic dependency and the welfare state. Acta Sociologica 33(3): 235-250. doi:10.1177/000169939003300305.

Hoem, J.M. and Kreyenfeld, M. (2006a). Anticipatory analysis and its alternatives in life-course research: Part 1: Education and first childbearing. Demographic Research 15(16): 461-484. doi:10.4054/DemRes.2006.15.16.

Hoem, J.M. and Kreyenfeld, M. (2006b). Anticipatory analysis and its alternatives in life-course research: Part 2: Two interacting processes. Demographic Research 15(17): 485-498. doi:10.4054/DemRes.2006.15.17.

Istat (2016). Matrimoni, separazioni e divorzi [electronic resource]. Rome: Istat. http://www.istat.it.

Jalovaara, M. (2003). The joint effects of marriage partners' socioeconomic positions on the risk of divorce. Demography 40(1): 67-81. doi:10.1353/dem.2003.0004.

Johnson, W.R. and Skinner, J. (1986). Labor supply and marital separation. The American Economic Review 76(3): 455-469.

Kalmijn, M. and Poortman, A.-R. (2006). His or her divorce? The gendered nature of divorce and its determinants. European Sociological Review 22(2): 201-214. doi:10.1093/esr/jci052.

Kaplan, A. and Stier, H. (2010). Political economy of family life: Welfare regimes, economic resources and divorce. Paper presented at the European Population Conference, Vienna, Austria, August 31-September 3, 2010.

Klesment, M. and Van Bavel, J. (2017). The reversal of the gender gap in education, motherhood, and women as main earners in Europe. European Sociological Review 33(3): 465-481.

Kulu, H. and Vikat, A. (2007). Fertility differences by housing type: The effect of housing conditions or of selective moves? Demographic Research 17(26): 775802. doi:10.4054/DemRes.2007.17.26.

Liefbroer, A.C. and Dourleijn, E. (2006). Unmarried cohabitation and union stability: Testing the role of diffusion using data from 16 European countries. Demography 43(2): 203-221. doi:10.1353/dem.2006.0018. 
Lillard, L.A. (1993). Simultaneous equations for hazards: marriage duration and fertility timing. Journal of Econometrics 56(1-2): 189-217. doi:10.1016/0304-4076(93) 90106-F.

Lillard, L.A., Brien, M.J., and Waite, L.J. (1995). Premarital cohabitation and subsequent marital dissolution: A matter of self-selection? Demography 32(3): 437-457. doi:10.2307/2061690.

Lillard, L.A. and Panis, C.W. (1996). Marital status and mortality: The role of health. Demography 33(3): 313-327. doi:10.2307/2061764.

Lyngstad, T.H. and Jalovaara, M. (2010). A review of the antecedents of union dissolution. Demographic Research 23(10): 257-292. doi:10.4054/DemRes. 2010.23.10.

Matysiak, A., Styrc, M., and Vignoli, D. (2014). The educational gradient in marital disruption: A meta-analysis of European research findings. Population Studies 68(2): 197-215. doi:10.1080/00324728.2013.856459.

Matysiak, A. and Szalma, I. (2014). Effects of parental leave policies on second birth risks and women's employment entry. Population 69(4): 599-636.

Matysiak, A. and Vignoli, D. (2013). Diverse effects of women's employment on fertility: Insights from Italy and Poland. European Journal of Population 29(3): 273-302. doi:10.1007/s10680-013-9287-4.

Matysiak, A. and Węziak-Białowolska, D. (2016). Country-specific conditions for work and family reconciliation: An attempt at quantification. European Journal of Population 32(4): 475-510. doi:10.1007/s10680-015-9366-9.

Mencarini, L. and Vignoli, D. (2017). Employed women and marital union stability: It helps when men help. Journal of Family Issues 39(5): 1348-1373. doi:10.1177/ $0192513 X 17710283$.

Neyer, G. (2003). Family policies and low fertility in Western Europe. Journal of Population and Social Security 1(Supplement)(286): 46-93.

OECD (2008). Benefits and wages [electronic resource]. Paris: OECD. http://www.oecd.org/els/benefitsandwagesstatistics.htm.

OECD (2011). Doing better for families [electronic resource]. Paris: OECD. http://www.oecd.org/social/soc/doingbetterforfamilies.htm. 
Vignoli et al.: The positive impact of women's employment on divorce: Context, selection, or anticipation?

Oláh, L.S. (2001). Gender and family stability: Dissolution of the first parental union in Sweden and Hungary. Demographic Research 4(2): 29-96. doi:10.4054/Dem Res.2001.4.2.

Oláh, L.S. and Gähler, M. (2014). Gender equality perceptions, division of paid and unpaid work, and partnership dissolution in Sweden. Social Forces 93(2): 571594. doi:10.1093/sf/sou066.

Oppenheimer, V.K. (1994). Women's rising employment and the future of the family in industrial societies. Population and Development Review 20(2): 293-342. doi: $10.2307 / 2137521$.

Oppenheimer, V.K. (1997). Women's employment and the gain to marriage: The specialization and trading model. Annual Review of Sociology 23: 431-453. doi:10.1146/annurev.soc.23.1.431.

Ostner, I. (1993). Slow motion: Women, work and the family in Germany. In: Lewis, J. (ed.). Women and social policies in Europe. Cheltenham: Edward Elgar: 92115 .

Özcan, B. and Breen, R. (2012). Marital instability and female labor supply. Annual Review of Sociology 38: 463-481. doi:10.1146/annurev-soc-071811-145457.

Papps, K.L. (2006). The effects of divorce risk on the labour supply of married couples. Bonn: Institute for the Study of Labour (IZA Discussion Paper 2395).

Parsons, T. (1940). An analytical approach to the theory of social stratification. American Journal of Sociology 45(6): 841-862. doi:10.1086/218489.

Pascall, G. and Manning, N. (2000). Gender and social policy: Comparing welfare states in Central and Eastern Europe and the former Soviet Union. Journal of European Social Policy 10(3): 240-266. doi:10.1177/a013497.

Perelli-Harris, B., Mynarska, M., Berrington, A., Evans, A., Berghammer, C., Isupova, O., Keizer, R., Klärner, A., Lappegård, T., and Vignoli, D. (2014). Towards a new understanding of cohabitation: Insights from focus group research across Europe and Australia. Demographic Research 31(34): 1043-1078. doi:10.4054/ DemRes.2014.31.34.

Perelli-Harris, B. and Sánchez Gassen, N. (2012). How similar are cohabitation and marriage? Legal approaches to cohabitation across Western Europe. Population and Development Review 38(3): 435-467. doi:10.1111/j.1728-4457.2012.005 11.x. 
Poortman, A.-R. (2005). How work affects divorce: The mediating role of financial and time pressures. Journal of Family Issues 26(2): 168-195. doi:10.1177/019251 $3 \times 04270228$.

Raz-Yurovich, L. (2012). Economic determinants of divorce among dual-earner couples: Jews in Israel. European Journal of Population 28(2): 177-203. doi:10.1007/s10680-012-9256-3.

Rogers, S.J. (1999). Wives' income and marital quality: Are there reciprocal effects? Journal of Marriage and Family 61(1): 123-132. doi:10.2307/353888 .

Rosenfeld, R.A., Trappe, H., and Gornick, J.C. (2004). Gender and work in Germany: Before and after reunification. Annual Review of Sociology 30: 103-124. doi:10.1146/annurev.soc.30.012703.110531.

Ruggles, S. (1997). The rise of divorce and separation in the United States, 1880-1990. Demography 34(4): 455-466. doi:10.2307/3038300.

Salvini, S. and Vignoli, D. (2011). Things change: Women's and men's marital disruption dynamics in Italy during a time of social transformations, 1970-2003. Demographic Research 24(5): 145-174. doi:10.4054/DemRes.2011.24.5.

Sayer, L.C. and Bianchi, S.M. (2000). Women's economic independence and the probability of divorce: A review and reexamination. Journal of Family Issues 21(7): 906-943. doi:10.1177/019251300021007005.

Schoen, R., Astone, N.M., Kim, Y.J., Rothert, K., and Standish, N.J. (2002). Women's employment, marital happiness, and divorce. Social Forces 81(2): 643-662. doi:10.1353/sof.2003.0019.

Sigle-Rushton, W. (2010). Men's unpaid work and divorce: Reassessing specialization and trade in British families. Feminist Economics 16(2): 1-26. doi:10.1080/ 13545700903448801 .

Simpson, I.H. and England, P. (1981). Conjugal work roles and marital solidarity. Journal of Family Issues 2(2): 180-204. doi:10.1177/0192513X8100200205.

Stevenson, B. and Wolfers, J. (2007). Marriage and divorce: Changes and their driving forces. Journal of Economic Perspectives 21(2): 27-52. doi:10.1257/jep.21.2.27.

Styrc, M. and Matysiak, A. (2012). Women's employment and marital stability: The role of the context. Studia Demograficzne 1(161): 81-101. doi:10.2478/v10274012-0004-9. 
Vignoli et al.: The positive impact of women's employment on divorce: Context, selection, or anticipation?

Szelewa, D. (2012). Childcare policies and gender relations in Eastern Europe: Hungary and Poland compared. Berlin: Harriet Taylor Mill-Institute (Discussion paper 17).

Szikra, D. and Szelewa, D. (2010). Do Central and Eastern European countries fit the 'Western' picture? The example of family policies in Hungary and Poland. In: Klenner, C. and Leiber, S. (eds.). Welfare states and gender inequality in Central and Eastern Europe. Brussels: ETUI: 81-116.

Treas, J. and Widmer, E.D. (2000). Married women's employment over the life course: Attitudes in cross-national perspective. Social Forces 78(4): 1409-1436.

Unterhofer, U. and Wrohlich, K. (2017). Fathers, parental leave and gender norms. Berlin: German Institute for Economic Research (Discussion Paper Series 1657).

Van Damme, M. and Kalmijn, M. (2014). The dynamic relationships between union dissolution and women's employment: A life-history analysis of 16 countries. Social Science Research 48: 261-278. doi:10.1016/j.ssresearch.2014.06.009.

Van Damme, M., Kalmijn, M., and Uunk, W. (2009). The employment of separated women in Europe: Individual and institutional determinants. European Sociological Review 25(2): 183-197. doi:10.1093/esr/jen042.

Vignoli, D. (2013). The role of work experience in shaping the entry into motherhood: A study for Italy. Population Review 52(2): 99-118.

Vignoli, D., Drefahl, S., and De Santis, G. (2012). Whose job instability affects the likelihood of becoming a parent in Italy? A tale of two partners. Demographic Research 26(2): 41-62. doi:10.4054/DemRes.2012.26.2.

Vignoli, D. and Ferro, I. (2009). Rising marital disruption in Italy and its correlates. Demographic Research 20(4): 11-36. doi:10.4054/DemRes.2009.20.4. 


\section{Appendix}

\section{Table A-1: Time-constant and time-varying covariates of the equations for the transition to marital disruption, to employment entry, and to employment exit}

\begin{tabular}{|c|c|c|c|}
\hline & Marital disruption & Employment entry & Employment exit \\
\hline \multicolumn{4}{|c|}{ Time-varying covariates (spline specification) } \\
\hline Duration of marriage & $x$ & & \\
\hline Duration of nonemployment & & $x$ & \\
\hline Duration of employment & & & $x$ \\
\hline Age & & $x$ & $x$ \\
\hline Calendar time & $\mathrm{x}$ & $x$ & $x$ \\
\hline Age of the youngest child & $x$ & $x$ & $x$ \\
\hline \multicolumn{4}{|l|}{ Time-varying covariates (categorical) } \\
\hline Number of children & $x$ & $x$ & $x$ \\
\hline Marriage order & $x$ & & \\
\hline Educational level & $x$ & $x$ & $x$ \\
\hline Employment & $x$ & & \\
\hline Order of nonemployment spell & & $\mathrm{x}$ & \\
\hline Marital status & & $\mathrm{x}$ & $\mathrm{x}$ \\
\hline Work experience & & $x$ & $x$ \\
\hline Order of employment spell & & & $x$ \\
\hline \multicolumn{4}{|l|}{ Time-constant covariates } \\
\hline Parental divorce & $x$ & & \\
\hline Parental education & $x$ & $x$ & $\mathrm{x}$ \\
\hline Age at first marriage & $x$ & & \\
\hline Cohabitation prior to first marriage & $x$ & & \\
\hline Conception/birth prior to first marriage & $x$ & & \\
\hline Mother's employment & & $x$ & $\mathrm{x}$ \\
\hline
\end{tabular}

Note: In Model M3 the indicator of being employed is substituted by a conditional spline for the time since entry into employment. 
Vignoli et al.: The positive impact of women's employment on divorce: Context, selection, or anticipation?

Table A-2: Parameter estimates for marital disruption, Germany

\begin{tabular}{|c|c|c|c|c|c|c|c|c|}
\hline \multirow[b]{2}{*}{ Explanatory variables } & \multicolumn{3}{|c|}{$\begin{array}{l}\text { Single-process } \\
\text { model }\end{array}$} & \multicolumn{3}{|c|}{$\begin{array}{l}\text { Multi-process model } \\
\text { with indicator of } \\
\text { being employed } \\
\text { (Model M2) }\end{array}$} & \multicolumn{2}{|c|}{$\begin{array}{l}\text { Multi-process model } \\
\text { with duration } \\
\text { dependence since } \\
\text { entry into } \\
\text { employment } \\
\text { (Model M3) }\end{array}$} \\
\hline & Coeff. & & SE & Coeff. & & SE & Coeff. & SE \\
\hline Intercept & -4.04 & * & 2.18 & -3.69 & & 2.49 & -3.71 & 2.52 \\
\hline \multicolumn{9}{|l|}{ Duration of marriage } \\
\hline $0-2$ years (slope) & 0.64 & * & 0.33 & 0.66 & * & 0.36 & 0.66 * & 0.37 \\
\hline $2-4$ years (slope) & -0.01 & & 0.23 & 0.00 & & 0.24 & 0.01 & 0.24 \\
\hline $4-7$ years (slope) & -0.17 & & 0.13 & -0.15 & & 0.14 & -0.15 & 0.14 \\
\hline 7-10 years (slope) & 0.08 & & 0.11 & 0.08 & & 0.12 & 0.08 & 0.12 \\
\hline >10 years (slope) & -0.05 & & 0.04 & -0.04 & & 0.04 & -0.04 & 0.04 \\
\hline \multicolumn{9}{|l|}{ Calendar time } \\
\hline 1971-1979 (slope) & -0.13 & & 0.26 & -0.17 & & 0.30 & -0.16 & 0.30 \\
\hline 1980-1989 (slope) & -0.03 & & 0.05 & -0.03 & & 0.06 & -0.04 & 0.06 \\
\hline 1990-1999 (slope) & 0.08 & ** & 0.03 & 0.08 & ** & 0.04 & $0.08^{* *}$ & 0.04 \\
\hline 2000-2004 (slope) & -0.05 & & 0.06 & -0.05 & & 0.07 & -0.05 & 0.07 \\
\hline 2005-2011 (slope) & 0.04 & & 0.10 & 0.04 & & 0.11 & 0.04 & 0.11 \\
\hline \multicolumn{9}{|c|}{ Age of the youngest child (duration since conception) } \\
\hline Pregnancy: 0-9 months (slope) & 1.17 & & 1.30 & 1.19 & & 1.41 & 1.18 & 1.44 \\
\hline Child aged $0-3$ years (slope) & 0.24 & & 0.15 & 0.23 & & 0.16 & 0.23 & 0.16 \\
\hline Child aged $3-7$ years (slope) & 0.03 & & 0.08 & 0.03 & & 0.09 & 0.03 & 0.09 \\
\hline Child over 7 years old (slope) & -0.01 & & 0.04 & -0.01 & & 0.04 & -0.01 & 0.04 \\
\hline \multicolumn{9}{|l|}{ Number of children (ref. = no children) } \\
\hline One & -2.10 & ** & 0.87 & -2.19 & ** & 0.97 & $-2.21 * *$ & 0.99 \\
\hline Two & -0.20 & & 0.21 & -0.24 & & 0.23 & -0.25 & 0.24 \\
\hline Three or more & -0.14 & & 0.27 & -0.16 & & 0.30 & -0.16 & 0.30 \\
\hline \multicolumn{9}{|l|}{ Parental divorce (ref. = no divorce) } \\
\hline Yes & 0.33 & & 0.35 & 0.34 & & 0.39 & 0.35 & 0.40 \\
\hline \multicolumn{9}{|c|}{ Parental education (ref. = no parent with higher education) } \\
\hline At least one parent with tertiary education & -0.04 & & 0.22 & -0.07 & & 0.25 & -0.07 & 0.26 \\
\hline \multicolumn{9}{|c|}{ Age at first marriage (ref. $=19$ years or younger) } \\
\hline $20-23$ years & -0.39 & & 0.26 & -0.44 & & 0.30 & -0.46 & 0.31 \\
\hline $24-27$ years & -0.56 & * & 0.30 & -0.57 & * & 0.34 & -0.60 * & 0.35 \\
\hline 28 or more years & -1.01 & ** & 0.39 & -1.04 & ** & 0.44 & $-1.09 * *$ & 0.46 \\
\hline \multicolumn{9}{|l|}{ Marriage order (ref. = first marriage) } \\
\hline Higher order marriage & 0.12 & & 0.81 & -0.17 & & 0.82 & -0.27 & 0.82 \\
\hline \multicolumn{9}{|c|}{ Conception/birth prior to first marriage (ref. = no conception prior to marriage) } \\
\hline First conception prior to first marriage & 0.38 & * & 0.22 & 0.39 & & 0.26 & 0.40 & 0.26 \\
\hline First birth prior to first marriage & 0.68 & ** & 0.26 & 0.72 & ** & 0.29 & $0.73^{* *}$ & 0.30 \\
\hline \multicolumn{9}{|l|}{ Cohabitation prior to first marriage $($ ref. $=$ no) } \\
\hline Yes & 0.53 & ** & 0.21 & 0.54 & ** & 0.23 & $0.55^{* *}$ & 0.24 \\
\hline \multicolumn{9}{|l|}{ Educational level (ref. = tertiary) } \\
\hline Secondary & 0.01 & & 0.23 & -0.08 & & 0.26 & -0.08 & 0.27 \\
\hline Vocational/primary & -0.17 & & 0.33 & -0.31 & & 0.40 & -0.33 & 0.42 \\
\hline In education & 0.49 & & 0.33 & 0.17 & & 0.38 & 0.16 & 0.39 \\
\hline \multicolumn{9}{|l|}{ Indicator of being employed (ref. = no) } \\
\hline Yes & 0.30 & * & 0.17 & 0.10 & & 0.24 & & \\
\hline \multicolumn{9}{|l|}{ Duration since entry into employment } \\
\hline Entry into employment (intercept) & & & & & & & 0.06 & 0.28 \\
\hline Change over time (slope) & & & & & & & 0.01 & 0.02 \\
\hline
\end{tabular}


Table A-3: Parameter estimates for marital disruption, Hungary

\begin{tabular}{|c|c|c|c|c|c|c|c|c|}
\hline \multirow[b]{2}{*}{ Explanatory variable } & \multicolumn{2}{|c|}{$\begin{array}{l}\text { Single-process } \\
\text { model }\end{array}$} & \multicolumn{3}{|c|}{$\begin{array}{l}\text { Multi-process model } \\
\text { with indicator of } \\
\text { being employed } \\
\text { (Model M2) }\end{array}$} & \multicolumn{3}{|c|}{$\begin{array}{l}\text { Multi-process model } \\
\text { with duration } \\
\text { dependence since } \\
\text { entry into } \\
\text { employment } \\
\text { (Model M3) }\end{array}$} \\
\hline & Coeff. & SE & Coeff. & & SE & Coeff. & & SE \\
\hline Intercept & $-4.25^{* * *}$ & 0.89 & -4.29 & *** & 0.92 & -4.28 & $* * *$ & 0.92 \\
\hline \multicolumn{9}{|l|}{ Duration of marriage } \\
\hline $0-2$ years (slope) & $1.02^{* * *}$ & 0.20 & 1.02 & $* \star \star$ & 0.21 & 1.02 & $* \star \star$ & 0.21 \\
\hline $2-4$ years (slope) & -0.15 & 0.12 & -0.15 & & 0.13 & -0.16 & & 0.13 \\
\hline 4-7 years (slope) & 0.14 * & 0.08 & 0.14 & * & 0.08 & 0.14 & * & 0.08 \\
\hline $7-10$ years (slope) & -0.04 & 0.07 & -0.04 & & 0.07 & -0.04 & & 0.07 \\
\hline >10 years (slope) & -0.01 & 0.02 & -0.01 & & 0.02 & -0.01 & & 0.02 \\
\hline \multicolumn{9}{|l|}{ Calendar time } \\
\hline 1971-1979 (slope) & -0.12 & 0.10 & -0.12 & & 0.10 & -0.12 & & 0.10 \\
\hline 1980-1989 (slope) & -0.01 & 0.03 & -0.01 & & 0.03 & -0.01 & & 0.03 \\
\hline 1990-1999 (slope) & 0.03 & 0.02 & 0.03 & & 0.02 & 0.03 & & 0.02 \\
\hline 2000-2004 (slope) & -0.05 & 0.04 & -0.05 & & 0.04 & -0.05 & & 0.04 \\
\hline 2005-2011 (slope) & 0.08 & 0.06 & 0.08 & & 0.06 & 0.08 & & 0.06 \\
\hline \multicolumn{9}{|c|}{ Age of the youngest child (duration since conception) } \\
\hline Pregnancy: 0-9 months (slope) & 0.94 & 0.67 & 0.93 & & 0.68 & 0.93 & & 0.68 \\
\hline Child aged $0-3$ years (slope) & 0.04 & 0.08 & 0.05 & & 0.09 & 0.04 & & 0.09 \\
\hline Child aged $3-7$ years (slope) & 0.07 & 0.05 & 0.07 & & 0.05 & 0.07 & & 0.05 \\
\hline Child over 7 years old (slope) & -0.02 & 0.02 & -0.02 & & 0.02 & -0.02 & & 0.02 \\
\hline \multicolumn{9}{|l|}{ Number of children (ref. = no children) } \\
\hline One & $-1.69^{* \star *}$ & 0.44 & -1.70 & *** & 0.45 & -1.70 & 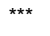 & 0.46 \\
\hline Two & $-0.65^{* * *}$ & 0.13 & -0.64 & *** & 0.13 & -0.65 & *** & 0.13 \\
\hline Three or more & $-0.72^{\star \star *}$ & 0.19 & -0.73 & *** & 0.19 & -0.73 & $* \star *$ & 0.19 \\
\hline \multicolumn{9}{|l|}{ Parental divorce (ref. = no divorce) } \\
\hline Yes & $0.48^{* * *}$ & 0.14 & 0.47 & *** & 0.14 & 0.47 & $* \star \star *$ & 0.14 \\
\hline \multicolumn{9}{|c|}{ Parental education (ref. = no parent with higher education) } \\
\hline At least one parent with tertiary education & $0.40^{* * *}$ & 0.15 & 0.41 & *** & 0.15 & 0.41 & $* * *$ & 0.15 \\
\hline \multicolumn{9}{|c|}{ Age at first marriage (ref. $=19$ years or younger) } \\
\hline $20-23$ years & $-0.26 * *$ & 0.12 & -0.24 & ** & 0.12 & -0.24 & ** & 0.12 \\
\hline $24-27$ years & $-0.54^{* * *}$ & 0.17 & -0.53 & *** & 0.17 & -0.53 & *** & 0.18 \\
\hline 28 or more years & $-0.92 * * *$ & 0.27 & -0.91 & *** & 0.27 & -0.91 & $* * *$ & 0.27 \\
\hline \multicolumn{9}{|l|}{ Marriage order (ref. = first marriage) } \\
\hline Higher order marriage & $0.52 *$ & 0.30 & 0.53 & * & 0.30 & 0.53 & * & 0.30 \\
\hline \multicolumn{9}{|c|}{ Conception/birth prior to first marriage (ref. $=$ no conception prior to marriage) } \\
\hline First conception prior to first marriage & $0.25^{* *}$ & 0.12 & 0.25 & ** & 0.12 & 0.25 & ** & 0.12 \\
\hline First birth prior to first marriage & $0.60^{* * *}$ & 0.22 & 0.59 & *** & 0.22 & 0.59 & $* \star *$ & 0.22 \\
\hline \multicolumn{9}{|c|}{ Cohabitation prior to first marriage $($ ref. $=$ no $)$} \\
\hline Yes & $0.68^{* * *}$ & 0.13 & 0.67 & *** & 0.13 & 0.67 & $* * *$ & 0.13 \\
\hline \multicolumn{9}{|l|}{ Educational level (ref. = tertiary) } \\
\hline Secondary & -0.15 & 0.14 & -0.11 & & 0.15 & -0.11 & & 0.15 \\
\hline Vocational/primary & -0.18 & 0.18 & -0.13 & & 0.18 & -0.14 & & 0.19 \\
\hline In education & 0.13 & 0.16 & 0.16 & & 0.17 & 0.16 & & 0.18 \\
\hline \multicolumn{9}{|l|}{ Indicator of being employed (ref. = no) } \\
\hline Yes & 0.13 & 0.12 & 0.15 & & 0.14 & & & \\
\hline \multicolumn{9}{|l|}{ Duration since entry into employment } \\
\hline Entry into employment (intercept) & & & & & & 0.14 & & 0.15 \\
\hline Change over time (slope) & & & & & & 0.00 & & 0.01 \\
\hline
\end{tabular}


Vignoli et al.: The positive impact of women's employment on divorce: Context, selection, or anticipation?

Table A-4: Parameter estimates for marital disruption, Italy

\begin{tabular}{|c|c|c|c|c|c|c|c|c|}
\hline \multirow[b]{2}{*}{ Explanatory variable } & \multicolumn{3}{|c|}{$\begin{array}{l}\text { Single-process } \\
\text { model }\end{array}$} & \multicolumn{3}{|c|}{$\begin{array}{l}\text { Multi-process model } \\
\text { with indicator of } \\
\text { being employed } \\
\text { (Model M2) }\end{array}$} & \multicolumn{2}{|c|}{$\begin{array}{l}\text { Multi-process model } \\
\text { with duration } \\
\text { dependence since } \\
\text { entry into } \\
\text { employment } \\
\text { (Model M3) }\end{array}$} \\
\hline & Coeff. & & SE & Coeff. & & SE & Coeff. & SE \\
\hline \multicolumn{8}{|l|}{ Duration of marriage } & 0.99 \\
\hline $0-2$ years (slope) & -0.40 & $* \star *$ & 0.10 & -0.39 & $* \star *$ & 0.10 & $-0.39 * * *$ & 0.10 \\
\hline $2-4$ years (slope) & 0.11 & & 0.10 & 0.11 & & 0.10 & 0.12 & 0.10 \\
\hline 4-7 years (slope) & -0.01 & & 0.06 & 0.00 & & 0.07 & 0.01 & 0.07 \\
\hline $7-10$ years (slope) & 0.01 & & 0.06 & 0.01 & & 0.06 & 0.02 & 0.06 \\
\hline \multicolumn{8}{|l|}{ Calendar time } & 0.02 \\
\hline 1971-1979 (slope) & -0.10 & & 0.11 & -0.09 & & 0.11 & -0.10 & 0.11 \\
\hline 1980-1989 (slope) & 0.06 & $\star \star$ & 0.02 & 0.06 & $\star *$ & 0.02 & $0.06^{* *}$ & 0.02 \\
\hline 1990-1999 (slope) & 0.05 & $\star \star \star *$ & 0.01 & 0.05 & $* \star *$ & 0.02 & $0.05 * * *$ & 0.02 \\
\hline 2000-2004 (slope) & -0.05 & & 0.03 & -0.04 & & 0.03 & -0.05 & 0.03 \\
\hline 2005-2011 (slope) & 0.01 & & 0.04 & 0.01 & & 0.04 & 0.01 & 0.04 \\
\hline \multicolumn{9}{|c|}{ Age of the youngest child (duration since conception) } \\
\hline Pregnancy: 0-9 months (slope) & 0.52 & & 0.44 & 0.50 & & 0.44 & 0.51 & 0.44 \\
\hline Child aged $0-3$ years (slope) & -0.08 & & 0.06 & -0.08 & & 0.06 & -0.09 & 0.06 \\
\hline Child aged $3-7$ years (slope) & -0.01 & & 0.04 & -0.01 & & 0.04 & -0.01 & 0.04 \\
\hline Child over 7 years old (slope) & -0.02 & & 0.02 & -0.02 & & 0.02 & -0.02 & 0.02 \\
\hline \multicolumn{9}{|l|}{ Number of children (ref. = no children) } \\
\hline One & -0.84 & $\star \star \star$ & 0.29 & -0.83 & $* \star *$ & 0.29 & $-0.83^{\star \star *}$ & 0.29 \\
\hline Two & -0.41 & $\star \star \star *$ & 0.11 & -0.41 & $* \star *$ & 0.11 & $-0.42 * * *$ & 0.11 \\
\hline \multicolumn{9}{|l|}{ Parental divorce (ref. = no divorce) } \\
\hline $\begin{array}{l}\text { Yes } \\
\text { Parental education (ref. = no parent with }\end{array}$ & n) 0.80 & $\star \star \star *$ & 0.15 & 0.81 & $* \star *$ & 0.16 & $0.80 * * *$ & 0.16 \\
\hline $\begin{array}{l}\text { At least one parent with tertiary education } \\
\text { Age at first marriage (ref. }=19 \text { years or } y\end{array}$ & 0.58 & 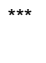 & 0.16 & 0.58 & *** & 0.17 & $0.57^{\star \star *}$ & 0.17 \\
\hline $20-23$ years & -0.21 & & 0.14 & -0.21 & & 0.14 & -0.19 & 0.14 \\
\hline $24-27$ years & -0.65 & $\star \star \star *$ & 0.16 & -0.65 & $* \star \star$ & 0.16 & $-0.60^{* \star *}$ & 0.16 \\
\hline $\begin{array}{l}28 \text { or more years } \\
\text { Marriage order (ref. = first marriage) }\end{array}$ & -0.96 & $\star \star \star *$ & 0.18 & -0.94 & $* \star *$ & 0.19 & $-0.85^{\star \star \star *}$ & 0.19 \\
\hline & $\begin{array}{l}-0.59 \\
\text { ption pric }\end{array}$ & \multicolumn{7}{|c|}{ Conception/birth prior to first marriage (ref. = no conception prior to marriage) } \\
\hline First conception prior to first marriage & 0.57 & $\star \star \star *$ & 0.11 & 0.58 & $\star \star \star *$ & 0.11 & $0.57^{\star \star \star}$ & 0.11 \\
\hline First birth prior to first marriage & 0.71 & *** & 0.16 & 0.71 & $* \star *$ & 0.17 & $0.71 * * *$ & 0.17 \\
\hline \multicolumn{9}{|c|}{ Cohabitation prior to first marriage $($ ref. $=$ no) } \\
\hline Yes & 0.31 & $\star \star \star$ & 0.12 & 0.30 & ** & 0.12 & $0.30^{* *}$ & 0.12 \\
\hline \multicolumn{9}{|l|}{ Educational level (ref. = tertiary) } \\
\hline Secondary & -0.16 & & 0.13 & -0.18 & & 0.13 & -0.15 & 0.13 \\
\hline Vocational & -0.25 & & 0.16 & -0.27 & & 0.17 & -0.24 & 0.17 \\
\hline Primary & -0.42 & *** & 0.14 & -0.46 & *** & 0.15 & $-0.44^{* \star *}$ & 0.15 \\
\hline $\begin{array}{l}\text { In education } \\
\text { Indicator of being employed (ref. = no) }\end{array}$ & 0.34 & & 0.21 & 0.31 & & 0.22 & 0.32 & 0.22 \\
\hline $\begin{array}{l}\text { Yes } \\
\text { Duration since entry into employment }\end{array}$ & 0.40 & $\star \star \star *$ & 0.08 & 0.32 & $* * *$ & 0.10 & & \\
\hline Entry into employment (intercept) & & & & & & & $0.43^{\star \star *}$ & 0.11 \\
\hline Change over time (slope) & & & & & & & $-0.02 * *$ & 0.01 \\
\hline
\end{tabular}


Table A-5: Parameter estimates for marital disruption, Poland

\begin{tabular}{|c|c|c|c|c|c|c|c|c|c|}
\hline \multirow[b]{2}{*}{ Explanatory variable } & \multicolumn{3}{|c|}{$\begin{array}{l}\text { Single-process } \\
\text { model }\end{array}$} & \multicolumn{3}{|c|}{$\begin{array}{l}\text { Multi-process model } \\
\text { with indicator of } \\
\text { being employed } \\
\text { (Model M2) }\end{array}$} & \multicolumn{3}{|c|}{$\begin{array}{l}\text { Multi-process model } \\
\text { with duration } \\
\text { dependence since } \\
\text { entry into } \\
\text { employment } \\
\text { (Model M3) }\end{array}$} \\
\hline & Coeff. & & SE & Coeff. & & SE & Coeff. & & SE \\
\hline \multicolumn{10}{|l|}{ Duration of marriage } \\
\hline $0-2$ years (slope) & 0.32 & * & 0.18 & 0.32 & * & 0.18 & 0.32 & * & 0.18 \\
\hline 2-4 years (slope) & 0.24 & ** & 0.12 & 0.25 & ** & 0.12 & 0.25 & ** & 0.12 \\
\hline 4-7 years (slope) & -0.13 & * & 0.07 & -0.13 & * & 0.07 & -0.13 & * & 0.07 \\
\hline $7-10$ years (slope) & 0.13 & ** & 0.06 & 0.14 & ** & 0.06 & 0.14 & ** & 0.06 \\
\hline \multicolumn{9}{|l|}{ Calendar time } & 0.02 \\
\hline 1971-1979 (slope) & 0.13 & & 0.23 & 0.11 & & 0.25 & 0.11 & & 0.28 \\
\hline 1980-1989 (slope) & -0.01 & & 0.04 & -0.01 & & 0.04 & -0.01 & & 0.04 \\
\hline 1990-1999 (slope) & -0.14 & * & 0.08 & -0.13 & * & 0.08 & -0.13 & * & 0.08 \\
\hline 2000-2004 (slope) & 0.10 & $* *$ & 0.01 & 0.10 & $* * *$ & 0.01 & 0.10 & $* * *$ & 0.01 \\
\hline $2005-2011$ (slope) & -0.06 & ** & 0.03 & -0.05 & * & 0.03 & -0.05 & * & 0.03 \\
\hline \multicolumn{10}{|c|}{ Age of the youngest child (duration since conception) } \\
\hline Pregnancy: 0-9 months (slope) & 1.79 & ** & 0.75 & 1.80 & ** & 0.76 & 1.80 & ** & 0.77 \\
\hline Child aged $0-3$ years (slope) & 0.02 & & 0.07 & 0.01 & & 0.08 & 0.01 & & 0.08 \\
\hline Child aged $3-7$ years (slope) & 0.10 & ** & 0.04 & 0.09 & ** & 0.04 & 0.09 & ** & 0.04 \\
\hline Child over 7 years old (slope) & -0.05 & ** & 0.02 & -0.05 & $* \star *$ & 0.02 & -0.05 & *** & 0.02 \\
\hline \multicolumn{10}{|l|}{ Number of children (ref. = no children) } \\
\hline One & -1.71 & ** & 0.53 & -1.70 & $* \star *$ & 0.54 & -1.70 & $* * *$ & 0.54 \\
\hline Two & -0.47 & ** & 0.11 & -0.49 & $* * *$ & 0.11 & 0.34 & $* * *$ & 0.11 \\
\hline $\begin{array}{l}\text { Three or more } \\
\text { Parental divorce (ref. = no divorce) }\end{array}$ & -0.72 & ** & 0.16 & -0.72 & *** & 0.17 & -0.49 & *** & 0.11 \\
\hline Yes & 0.67 & ** & 0.12 & 0.64 & $* * *$ & 0.13 & 0.64 & *** & 0.13 \\
\hline Parents never lived together & 0.11 & & 0.37 & 0.11 & & 0.39 & 0.11 & & 0.39 \\
\hline \multicolumn{10}{|c|}{ Parental education (ref. = no parent with higher education) } \\
\hline \multicolumn{10}{|c|}{ Age at first marriage (ref. $=19$ years or younger) } \\
\hline $20-23$ years & -0.45 & ** & 0.11 & -0.46 & *** & 0.12 & -0.46 & *** & 0.12 \\
\hline 24-27 years & -0.66 & ** & 0.14 & -0.68 & $* * *$ & 0.15 & -0.68 & $* * *$ & 0.15 \\
\hline $\begin{array}{l}28 \text { or more years } \\
\text { Marriage order (ref. = first marriage) }\end{array}$ & -0.74 & ** & 0.19 & -0.78 & *** & 0.20 & -0.78 & *** & 0.21 \\
\hline Higher order marriage & 0.31 & nrion & 0.37 & 0.02 & & 0.35 & 0.01 & & 0.36 \\
\hline \multicolumn{10}{|c|}{ Conception/birth prior to first marriage (ref. = no conception prior to marriage) } \\
\hline $\begin{array}{l}\text { First birth prior to first marriage } \\
\text { Cohabitation prior to first marriage (ref. }\end{array}$ & 0.67 & ** & 0.16 & 0.67 & $\star * \star *$ & 0.16 & 0.67 & *** & 0.16 \\
\hline $\begin{array}{l}\text { Yes } \\
\text { Educational level (ref. = tertiary) }\end{array}$ & 0.36 & ** & 0.10 & 0.34 & $* \star *$ & 0.11 & 0.34 & *** & 0.11 \\
\hline Secondary & -0.15 & & 0.12 & -0.14 & & 0.12 & -0.14 & & 0.12 \\
\hline Vocational & -0.27 & ** & 0.14 & -0.27 & * & 0.15 & -0.27 & * & 0.15 \\
\hline Primary & 0.06 & & 0.17 & 0.12 & & 0.18 & 0.12 & & 0.18 \\
\hline In education & 0.08 & & 0.18 & 0.05 & & 0.19 & 0.05 & & 0.19 \\
\hline Indicator of being employed (ref. = no) & & & & & & & & & \\
\hline $\begin{array}{l}\text { Yes } \\
\text { Duration since entry into employment }\end{array}$ & 0.20 & ** & 0.09 & 0.35 & $\star \star \star *$ & 0.12 & & & \\
\hline Entry into employment (intercept) & & & & & & & 0.35 & $* * *$ & 0.12 \\
\hline Change over time (slope) & & & & & & & 0.00 & & 0.01 \\
\hline
\end{tabular}


Vignoli et al.: The positive impact of women's employment on divorce: Context, selection, or anticipation?

Table A-6: Parameter estimates for employment entry, Germany

\begin{tabular}{|c|c|c|c|c|c|c|c|c|c|}
\hline \multirow[b]{2}{*}{ Explanatory variable } & \multicolumn{3}{|c|}{$\begin{array}{l}\text { Single-process } \\
\text { model }\end{array}$} & \multicolumn{3}{|c|}{$\begin{array}{l}\text { Multi-process model } \\
\text { with indicator of } \\
\text { being employed } \\
\text { (Model M2) }\end{array}$} & \multicolumn{3}{|c|}{$\begin{array}{l}\text { Multi-process mode } \\
\text { with duration } \\
\text { dependence since } \\
\text { entry into } \\
\text { employment } \\
\text { (Model M3) }\end{array}$} \\
\hline & Coeff. & & SE & Coeff. & & SE & Coeff. & & SE \\
\hline Intercept & 1.20 & $* \star * \star$ & 0.44 & 1.37 & $* \star * \star$ & 0.47 & 1.36 & 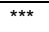 & 0.47 \\
\hline \multicolumn{10}{|l|}{ Time since entering nonemployment } \\
\hline $0-0.5$ years (slope) & -2.63 & 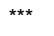 & 0.40 & -2.58 & $* \star \star$ & 0.44 & -2.58 & 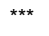 & 0.44 \\
\hline $0.5-1$ years (slope) & 0.24 & & 0.33 & 0.23 & & 0.35 & 0.23 & & 0.35 \\
\hline $1-3$ years (slope) & 0.09 & & 0.06 & 0.10 & & 0.07 & 0.10 & & 0.07 \\
\hline $3-5$ years (slope) & 0.05 & & 0.05 & 0.05 & & 0.05 & 0.05 & & 0.05 \\
\hline$>5$ years (slope) & -0.01 & & 0.01 & -0.01 & & 0.01 & -0.01 & & 0.01 \\
\hline \multicolumn{10}{|l|}{ Age } \\
\hline 15-19 years (slope) & 0.20 & $* \star \star$ & 0.04 & 0.20 & $* * *$ & 0.04 & 0.20 & $* \star * *$ & 0.04 \\
\hline 20-24 years (slope) & -0.05 & * & 0.03 & -0.05 & * & 0.03 & -0.05 & * & 0.03 \\
\hline 25-29 years (slope) & 0.02 & & 0.03 & 0.02 & & 0.03 & 0.02 & & 0.03 \\
\hline 30-39 years (slope) & -0.02 & & 0.02 & -0.02 & & 0.02 & -0.02 & & 0.02 \\
\hline 40-44 years (slope) & 0.06 & & 0.04 & 0.06 & & 0.04 & 0.07 & & 0.05 \\
\hline 45 or more years (slope) & -0.17 & $\star \star \star *$ & 0.06 & -0.16 & $\star \star$ & 0.07 & -0.17 & $* *$ & 0.07 \\
\hline \multicolumn{10}{|l|}{ Calendar time } \\
\hline 1970-1989 (slope) & -0.02 & $* *$ & 0.01 & -0.02 & ** & 0.01 & -0.02 & ** & 0.01 \\
\hline 1990-1993 (slope) & -0.12 & $* \star *$ & 0.03 & -0.12 & $* \star * *$ & 0.03 & -0.12 & $* \star \star *$ & 0.03 \\
\hline 1994-1997 (slope) & 0.01 & & 0.04 & 0.00 & & 0.04 & 0.00 & & 0.04 \\
\hline 1998-2003 (slope) & 0.03 & & 0.03 & 0.03 & & 0.03 & 0.03 & & 0.03 \\
\hline 2004-2007 (slope) & -0.08 & * & 0.04 & -0.08 & * & 0.05 & -0.08 & * & 0.05 \\
\hline 2008-2011 (slope) & 0.20 & & 0.23 & 0.20 & & 0.24 & 0.19 & & 0.24 \\
\hline \multicolumn{10}{|c|}{ Age of the youngest child (duration since conception) } \\
\hline Pregnancy 0-6 months (slope) & -0.15 & & 0.71 & -0.15 & & 0.78 & -0.15 & & 0.79 \\
\hline Pregnancy 6 months-child aged 6 months (slope) & -0.08 & & 0.34 & -0.08 & & 0.36 & -0.08 & & 0.37 \\
\hline Child aged 6 months -3 years (slope) & 0.45 & $* \star \star$ & 0.08 & 0.45 & $* \star * *$ & 0.08 & 0.45 & 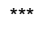 & 0.08 \\
\hline Child aged $3-5$ years (slope) & -0.12 & & 0.08 & -0.12 & & 0.08 & -0.12 & & 0.08 \\
\hline Child aged over 5 years (slope) & 0.00 & & 0.02 & 0.00 & & 0.02 & 0.01 & & 0.02 \\
\hline \multicolumn{10}{|l|}{ Number of children (ref. = no children) } \\
\hline One & -1.35 & $* \star \star$ & 0.23 & -1.36 & $* \star * *$ & 0.26 & -1.36 & 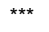 & 0.26 \\
\hline Two & -0.19 & ** & 0.09 & -0.19 & ** & 0.10 & -0.20 & ** & 0.10 \\
\hline Three or more & -0.41 & $\star \star \star *$ & 0.13 & -0.45 & 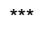 & 0.13 & -0.44 & 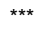 & 0.13 \\
\hline \multicolumn{10}{|l|}{ Mother's employment (ref. = no) } \\
\hline Yes & 0.04 & & 0.42 & -0.08 & & 0.44 & -0.09 & & 0.44 \\
\hline \multicolumn{10}{|c|}{ Parental education (ref. = no parent with higher education) } \\
\hline At least one parent with tertiary education & -0.13 & & 0.11 & -0.14 & & 0.11 & -0.15 & & 0.11 \\
\hline \multicolumn{10}{|l|}{ Order of nonemployment spell (ref. = first) } \\
\hline Second & -0.40 & & 0.40 & -0.39 & & 0.43 & -0.40 & & 0.43 \\
\hline Third & -0.39 & & 0.41 & -0.23 & & 0.44 & -0.25 & & 0.44 \\
\hline Fourth or next & -1.01 & ** & 0.42 & -0.75 & & 0.47 & -0.76 & & 0.46 \\
\hline \multicolumn{10}{|l|}{ Marital status $($ ref. $=$ married) } \\
\hline Single & 0.63 & $* \star \star$ & 0.08 & 0.62 & $* \star * *$ & 0.09 & 0.63 & $* \star \star *$ & 0.09 \\
\hline Divorced & 0.50 & $\star \star \star *$ & 0.12 & 0.31 & $\star *$ & 0.14 & & & \\
\hline Divorce (intercept) & & & & & & & 0.74 & 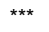 & 0.23 \\
\hline Duration since divorce (slope) & & & & & & & -0.09 & $* \star \star$ & 0.03 \\
\hline Widowed & 1 & & I & l & & I & 1 & & 1 \\
\hline
\end{tabular}


Table A-6: (Continued)

\begin{tabular}{|c|c|c|c|c|c|c|c|c|}
\hline \multirow[b]{2}{*}{ Explanatory variable } & \multicolumn{2}{|c|}{$\begin{array}{l}\text { Single-process } \\
\text { model } \\
\text { (Model M1) }\end{array}$} & \multicolumn{3}{|c|}{$\begin{array}{l}\text { Multi-process model } \\
\text { with indicator of } \\
\text { being employed } \\
\text { (Model M2) }\end{array}$} & \multicolumn{3}{|c|}{$\begin{array}{l}\text { Multi-process model } \\
\text { with duration } \\
\text { dependence since } \\
\text { entry into } \\
\text { employment } \\
\text { (Model M3) }\end{array}$} \\
\hline & Coeff. & SE & Coeff. & & SE & Coeff. & & SE \\
\hline \multicolumn{9}{|c|}{ Educational level (ref. = tertiary) } \\
\hline Secondary & $-0.70^{* * *}$ & 0.09 & -0.74 & $* \star \star *$ & 0.10 & -0.74 & *** & 0.10 \\
\hline Vocational/primary & $-2.17^{* \star *}$ & 0.14 & -2.22 & $* * *$ & 0.15 & -2.21 & *** & 0.15 \\
\hline In education & $-3.82 * \star 2 *$ & 0.10 & -3.88 & 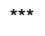 & 0.11 & -3.87 & *** & 0.11 \\
\hline \multicolumn{9}{|c|}{ Work experience $($ ref. $=$ none $)$} \\
\hline $0-3$ years & -0.21 & 0.40 & -0.04 & & 0.43 & -0.01 & & 0.43 \\
\hline $3-6$ years & -0.50 & 0.40 & -0.42 & & 0.44 & -0.40 & & 0.44 \\
\hline $6-10$ years & -0.48 & 0.41 & -0.45 & & 0.45 & -0.43 & & 0.45 \\
\hline 10 years or more & -0.50 & 0.44 & -0.53 & & 0.48 & -0.50 & & 0.48 \\
\hline
\end{tabular}


Vignoli et al.: The positive impact of women's employment on divorce: Context, selection, or anticipation?

Table A-7: Parameter estimates for employment entry, Hungary

\begin{tabular}{|c|c|c|c|c|c|c|c|c|c|}
\hline \multirow[b]{2}{*}{ Explanatory variables } & \multicolumn{3}{|c|}{$\begin{array}{l}\text { Single-process } \\
\text { model } \\
\text { (Model M1) }\end{array}$} & \multicolumn{3}{|c|}{$\begin{array}{l}\text { Multi-process model } \\
\text { with indicator of being } \\
\text { employed } \\
\text { (Model M2) }\end{array}$} & \multicolumn{3}{|c|}{$\begin{array}{l}\text { Multi-process model } \\
\text { with duration } \\
\text { dependence since } \\
\text { entry into employment } \\
\text { (Model M3) }\end{array}$} \\
\hline & Coeff. & & SE & $\overline{\text { Coeff. }}$ & & $\overline{\mathrm{SE}}$ & Coeff. & & $\overline{S E}$ \\
\hline Intercept & -1.21 & $* \star \star *$ & 0.11 & -1.30 & $* \star * \star$ & 0.12 & -1.30 & $\star \star * \star$ & 0.12 \\
\hline \multicolumn{10}{|l|}{ Time since entering nonemployment } \\
\hline $0-0.5$ years (slope) & -2.86 & $* \star *$ & 0.14 & -2.85 & $* * *$ & 0.17 & -2.84 & *** & 0.17 \\
\hline $0.5-1$ years (slope) & 0.44 & $* * *$ & 0.14 & 0.44 & *** & 0.16 & 0.44 & *** & 0.16 \\
\hline $1-3$ years (slope) & 0.27 & $* * *$ & 0.03 & 0.27 & $* * *$ & 0.03 & 0.27 & $* \star *$ & 0.03 \\
\hline $3-5$ years (slope) & -0.28 & $* * *$ & 0.03 & -0.28 & *** & 0.03 & -0.28 & $* * *$ & 0.03 \\
\hline$>5$ years (slope) & 0.03 & $\star * *$ & 0.01 & 0.03 & $* * *$ & 0.01 & 0.03 & $* * *$ & 0.01 \\
\hline \multicolumn{10}{|l|}{ Age } \\
\hline 15-19 years (slope) & 0.10 & $* * *$ & 0.02 & 0.09 & $* \star *$ & 0.02 & 0.10 & $* * *$ & 0.02 \\
\hline 20-24 years (slope) & -0.12 & $* * *$ & 0.01 & -0.12 & $* \star *$ & 0.02 & -0.12 & 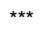 & 0.02 \\
\hline 25-29 years (slope) & -0.08 & $\star \star \star *$ & 0.02 & -0.07 & *** & 0.02 & -0.07 & *** & 0.02 \\
\hline 30-39 years (slope) & 0.04 & $* * *$ & 0.01 & 0.04 & $* * *$ & 0.01 & 0.04 & $* * *$ & 0.01 \\
\hline 40-44 years (slope) & -0.18 & $* * *$ & 0.02 & -0.18 & $* * *$ & 0.03 & -0.18 & $* * *$ & 0.03 \\
\hline 45 or more years (slope) & 0.03 & & 0.03 & 0.03 & & 0.03 & 0.03 & & 0.03 \\
\hline \multicolumn{10}{|l|}{ Calendar time } \\
\hline 1970-1989 (slope) & 0.15 & $\star \star \star *$ & 0.01 & 0.15 & $* \star *$ & 0.01 & 0.15 & $* * *$ & 0.01 \\
\hline 1990-1993 (slope) & -0.22 & $* \star *$ & 0.02 & -0.22 & $* \star *$ & 0.02 & -0.22 & $\star \star * \star$ & 0.02 \\
\hline 1994-1997 (slope) & 0.04 & * & 0.02 & 0.04 & * & 0.02 & 0.04 & * & 0.02 \\
\hline 1998-2003 (slope) & 0.02 & & 0.01 & 0.02 & & 0.01 & 0.02 & & 0.01 \\
\hline 2004-2007 (slope) & -0.02 & & 0.02 & -0.01 & & 0.02 & -0.01 & & 0.02 \\
\hline $2008-2011$ (slope) & -1.86 & $* \star *$ & 0.24 & -1.86 & $* \star *$ & 0.25 & -1.86 & $\star \star \star *$ & 0.25 \\
\hline \multicolumn{10}{|c|}{ Age of the youngest child (duration since conception) } \\
\hline Pregnancy $0-6$ months (slope) & 0.68 & *** & 0.23 & 0.67 & *** & 0.24 & 0.67 & *** & 0.24 \\
\hline Pregnancy 6 months-child aged 6 months (slope) & -1.39 & *** & 0.17 & -1.39 & *** & 0.17 & -1.39 & $* \star *$ & 0.17 \\
\hline Child aged 6 months -3 years (slope) & -0.06 & & 0.05 & -0.06 & & 0.05 & -0.06 & & 0.05 \\
\hline Child aged $3-5$ years (slope) & -0.09 & ** & 0.05 & -0.10 & $* *$ & 0.05 & -0.10 & ** & 0.05 \\
\hline Child aged over 5 years (slope) & -0.03 & $* \star *$ & 0.01 & -0.03 & *** & 0.01 & -0.03 & $* * *$ & 0.01 \\
\hline \multicolumn{10}{|l|}{ Number of children (ref. $=$ no children) } \\
\hline One & 0.49 & $* * *$ & 0.08 & 0.48 & $* \star *$ & 0.08 & 0.48 & $* \star *$ & 0.08 \\
\hline Two & -0.20 & $* * *$ & 0.05 & -0.20 & $* * *$ & 0.05 & -0.20 & $* * *$ & 0.05 \\
\hline Three or more & -0.43 & *** & 0.07 & -0.44 & *** & 0.07 & -0.45 & $\star \star \star *$ & 0.07 \\
\hline \multicolumn{10}{|l|}{ Mother's employment (ref. = no) } \\
\hline Yes & 0.00 & & 0.00 & 0.00 & & 0.00 & 0.00 & & 0.00 \\
\hline \multicolumn{10}{|c|}{ Parental education (ref. = no parent with higher education) } \\
\hline At least one parent with tertiary education & -0.24 & $* * *$ & 0.07 & -0.22 & *** & 0.07 & -0.22 & *** & 0.07 \\
\hline \multicolumn{10}{|l|}{ Order of nonemployment spell (ref. = first) } \\
\hline Second & -0.42 & $\star \star \star *$ & 0.16 & -0.44 & $* * *$ & 0.17 & -0.44 & *** & 0.17 \\
\hline Third & -0.14 & & 0.16 & -0.15 & & 0.17 & -0.16 & & 0.17 \\
\hline Fourth or next & -0.15 & & 0.17 & -0.17 & & 0.18 & -0.17 & & 0.18 \\
\hline \multicolumn{10}{|l|}{ Marital status (ref. = married) } \\
\hline Single & -0.04 & & 0.05 & -0.04 & & 0.05 & -0.04 & & 0.05 \\
\hline Divorced & -0.15 & ** & 0.07 & -0.15 & * & 0.08 & & & \\
\hline Divorce (intercept) & & & & & & & -0.05 & & 0.11 \\
\hline Duration since divorce (slope) & & & & & & & -0.02 & & 0.01 \\
\hline Widowed & -0.57 & $* * *$ & 0.14 & -0.56 & $* * *$ & 0.15 & -0.57 & *** & 0.15 \\
\hline
\end{tabular}


Table A-7: (Continued)

\begin{tabular}{|c|c|c|c|c|c|c|c|c|c|}
\hline \multirow[b]{2}{*}{ Explanatory variable } & \multicolumn{3}{|c|}{$\begin{array}{l}\text { Single-process } \\
\text { model }\end{array}$} & \multicolumn{3}{|c|}{$\begin{array}{l}\text { Multi-process model } \\
\text { with indicator of being } \\
\text { employed } \\
\text { (Model M2) }\end{array}$} & \multicolumn{3}{|c|}{$\begin{array}{l}\text { Multi-process model } \\
\text { with duration } \\
\text { dependence since } \\
\text { entry into employment } \\
\text { (Model M3) }\end{array}$} \\
\hline & Coeff. & & SE & Coeff. & & SE & Coeff. & & SE \\
\hline \multicolumn{10}{|c|}{ Educational level (ref. = tertiary) } \\
\hline Secondary & -0.62 & $* * *$ & 0.05 & -0.56 & $\star \star \star$ & 0.05 & -0.56 & $\star \star \star *$ & 0.05 \\
\hline Vocational/primary & -1.52 & $* \star \star$ & 0.07 & -1.47 & *** & 0.07 & -1.47 & $* \star \star$ & 0.07 \\
\hline In education & -2.30 & $* * *$ & 0.06 & -2.25 & $* \star *$ & 0.06 & -2.26 & $* * *$ & 0.06 \\
\hline \multicolumn{10}{|c|}{ Work experience $($ ref. $=$ none $)$} \\
\hline $0-3$ years & 1.15 & $* * *$ & 0.16 & 1.17 & $* * \star$ & 0.17 & 1.17 & $* * *$ & 0.17 \\
\hline $3-6$ years & 1.46 & $* * *$ & 0.17 & 1.47 & 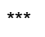 & 0.18 & 1.47 & 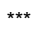 & 0.18 \\
\hline $6-10$ years & 1.57 & 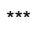 & 0.18 & 1.56 & 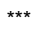 & 0.18 & 1.56 & 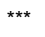 & 0.18 \\
\hline 10 years or more & 1.44 & $* * \star$ & 0.19 & 1.41 & 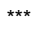 & 0.19 & 1.41 & 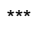 & 0.20 \\
\hline
\end{tabular}


Vignoli et al.: The positive impact of women's employment on divorce: Context, selection, or anticipation?

Table A-8: Parameter estimates for employment entry, Italy

\begin{tabular}{|c|c|c|c|c|c|c|c|c|}
\hline \multirow[b]{2}{*}{ Explanatory variable } & \multicolumn{3}{|c|}{$\begin{array}{l}\text { Single-process } \\
\text { model } \\
\text { (Model M1) }\end{array}$} & \multicolumn{3}{|c|}{$\begin{array}{l}\text { Multi-process model } \\
\text { with indicator of being } \\
\text { employed } \\
\text { (Model M2) }\end{array}$} & \multicolumn{2}{|c|}{$\begin{array}{l}\text { Multi-process model } \\
\text { with duration } \\
\text { dependence since } \\
\text { entry into employment } \\
\text { (Model M3) }\end{array}$} \\
\hline & Coeff. & & SE & $\overline{\text { Coeff. }}$ & & $\overline{\mathrm{SE}}$ & Coeff. & SE \\
\hline Intercept & -1.95 & $* \star \star *$ & 0.09 & -1.96 & *** & 0.09 & $-1.96^{* \star *}$ & 0.09 \\
\hline \multicolumn{9}{|l|}{ Time since entering nonemployment } \\
\hline $0-0.5$ years (slope) & -1.04 & $* * *$ & 0.09 & -1.06 & $* * \star$ & 0.10 & $-1.06 * * *$ & 0.10 \\
\hline $0.5-1$ years (slope) & -0.88 & $* * *$ & 0.09 & -0.87 & *** & 0.09 & $-0.87^{* \star *}$ & 0.09 \\
\hline $1-3$ years (slope) & -0.44 & $* * *$ & 0.03 & -0.44 & $* * *$ & 0.03 & $-0.44^{* * *}$ & 0.03 \\
\hline $3-5$ years (slope) & -0.10 & $* * *$ & 0.02 & -0.11 & *** & 0.02 & $-0.11^{* \star *}$ & 0.02 \\
\hline$>5$ years (slope) & -0.05 & $\star * *$ & 0.00 & -0.05 & $* \star *$ & 0.00 & $-0.05^{* * *}$ & 0.00 \\
\hline \multicolumn{9}{|l|}{ Age } \\
\hline 15-19 years (slope) & 0.60 & $* * *$ & 0.02 & 0.61 & $* * \star$ & 0.02 & $0.60 * * *$ & 0.02 \\
\hline 20-24 years (slope) & 0.06 & $* * *$ & 0.01 & 0.07 & $\star \star \star *$ & 0.01 & $0.07^{* \star *}$ & 0.01 \\
\hline 25-29 years (slope) & 0.06 & $\star \star \star *$ & 0.01 & 0.07 & $* \star \star$ & 0.01 & $0.07^{* \star *}$ & 0.01 \\
\hline 30-39 years (slope) & 0.01 & $* \star$ & 0.01 & 0.02 & ** & 0.01 & $0.02 * *$ & 0.01 \\
\hline 40-44 years (slope) & -0.03 & $* *$ & 0.02 & -0.03 & * & 0.02 & -0.03 * & 0.02 \\
\hline 45 or more years (slope) & -0.09 & $* * *$ & 0.02 & -0.09 & $* \star *$ & 0.02 & $-0.09 * * *$ & 0.02 \\
\hline \multicolumn{9}{|l|}{ Calendar time } \\
\hline 1970-1989 (slope) & -0.03 & $* * *$ & 0.00 & -0.03 & $* * *$ & 0.00 & $-0.03 * * *$ & 0.00 \\
\hline 1990-1993 (slope) & -0.06 & $\star \star \star *$ & 0.01 & -0.06 & $* \star *$ & 0.01 & $-0.06^{* \star *}$ & 0.01 \\
\hline 1994-1997 (slope) & 0.08 & *** & 0.01 & 0.08 & *** & 0.01 & $0.08^{* * *}$ & 0.01 \\
\hline 1998-1903 (slope) & 0.01 & & 0.01 & 0.01 & & 0.01 & 0.01 & 0.01 \\
\hline 2004-2007 (slope) & 0.05 & *** & 0.01 & 0.05 & $* * *$ & 0.01 & $0.05^{* * *}$ & 0.01 \\
\hline $2008-2011$ (slope) & -0.24 & $* \star *$ & 0.03 & -0.24 & $* \star *$ & 0.04 & -0.24 *** & 0.04 \\
\hline \multicolumn{9}{|c|}{ Age of the youngest child (duration since conception) } \\
\hline Pregnancy $0-6$ months (slope) & -1.69 & $* \star *$ & 0.44 & -1.68 & $* \star \star$ & 0.44 & $-1.69 * * *$ & 0.44 \\
\hline Pregnancy 6 months-child aged 6 months (slope) & 1.01 & *** & 0.17 & 1.01 & *** & 0.17 & $1.01 * * *$ & 0.17 \\
\hline Child aged 6 months -3 years (slope) & 0.22 & $* * *$ & 0.03 & 0.22 & $* * *$ & 0.03 & $0.22 * * \star$ & 0.03 \\
\hline Child aged $3-5$ years (slope) & 0.01 & & 0.03 & 0.01 & & 0.03 & 0.01 & 0.03 \\
\hline Child aged over 5 years (slope) & 0.02 & $* \star *$ & 0.01 & 0.01 & ** & 0.01 & 0.01 ** & 0.01 \\
\hline \multicolumn{9}{|l|}{ Number of children (ref. = no children) } \\
\hline One & -0.84 & $* * *$ & 0.16 & -0.83 & *** & 0.16 & $-0.84 * * *$ & 0.16 \\
\hline Two & -0.22 & $* * *$ & 0.04 & -0.22 & $* * *$ & 0.04 & $-0.21^{* * *}$ & 0.04 \\
\hline Three or more & -0.43 & *** & 0.06 & -0.43 & 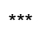 & 0.07 & $-0.43^{* * *}$ & 0.07 \\
\hline \multicolumn{9}{|l|}{ Mother's employment (ref. = no) } \\
\hline Yes & 0.36 & *** & 0.03 & 0.37 & *** & 0.03 & $0.37^{* * *}$ & 0.03 \\
\hline \multicolumn{9}{|c|}{ Parental education (ref. = no parent with higher education) } \\
\hline & \multicolumn{8}{|c|}{ Order of nonemployment spell (ref. = first) } \\
\hline Second & -0.80 & $* * *$ & 0.07 & -0.83 & $* * *$ & 0.07 & $-0.83^{* * *}$ & 0.07 \\
\hline Third & -0.77 & $\star * *$ & 0.08 & -0.85 & $* * *$ & 0.08 & $-0.85^{* * *}$ & 0.08 \\
\hline Fourth or next & -0.83 & $\star * *$ & 0.09 & -0.96 & $* * *$ & 0.09 & $-0.97^{* \star *}$ & 0.09 \\
\hline \multicolumn{9}{|l|}{ Marital status (ref. = married) } \\
\hline Single & 0.41 & $\star \star \star *$ & 0.03 & 0.42 & $* * *$ & 0.04 & $0.41^{* * *}$ & 0.04 \\
\hline Divorced & 0.73 & $\star \star \star *$ & 0.06 & 0.68 & $* \star *$ & 0.07 & & \\
\hline Divorce (intercept) & & & & & & & $0.62 * * *$ & 0.08 \\
\hline Duration since divorce (slope) & & & & & & & 0.01 & 0.01 \\
\hline Widowed & 0.15 & & 0.12 & 0.15 & & 0.12 & 0.16 & 0.12 \\
\hline
\end{tabular}


Table A-8: (Continued)

\begin{tabular}{|c|c|c|c|c|c|c|}
\hline \multirow[b]{2}{*}{ Explanatory variable } & \multicolumn{2}{|c|}{$\begin{array}{l}\text { Single-process } \\
\text { model }\end{array}$} & \multicolumn{2}{|c|}{$\begin{array}{l}\text { Multi-process model } \\
\text { with indicator of being } \\
\text { employed } \\
\text { (Model M2) }\end{array}$} & \multicolumn{2}{|c|}{$\begin{array}{l}\text { Multi-process model } \\
\text { with duration } \\
\text { dependence since } \\
\text { entry into employment } \\
\text { (Model M3) }\end{array}$} \\
\hline & Coeff. & SE & Coeff. & SE & Coeff. & SE \\
\hline \multicolumn{7}{|c|}{ Educational level (ref. = tertiary) } \\
\hline Secondary & $-0.24 * * *$ & 0.04 & $-0.24 * * *$ & 0.04 & $-0.24 * * *$ & 0.04 \\
\hline Vocational & $-0.18 * * *$ & 0.05 & $-0.17^{* * *}$ & 0.06 & $-0.17^{* * *}$ & 0.06 \\
\hline Primary & $-1.02 * \star * *$ & 0.04 & -1.02 *** & 0.05 & $-1.02 * * *$ & 0.05 \\
\hline In education & $-1.69 * \star *$ & 0.04 & $-1.69 * \star \star$ & 0.04 & $-1.69 * * *$ & 0.04 \\
\hline \multicolumn{7}{|c|}{ Work experience $($ ref. $=$ none $)$} \\
\hline $0-3$ years & $0.84^{\star * *}$ & 0.07 & $0.77^{* * *}$ & 0.07 & $0.77^{* * *}$ & 0.07 \\
\hline $3-6$ years & $0.51 * * *$ & 0.07 & $0.46^{* * *}$ & 0.07 & $0.46^{* * *}$ & 0.07 \\
\hline $6-10$ years & $0.36 * * *$ & 0.08 & $0.31 * * *$ & 0.08 & $0.31 * * *$ & 0.08 \\
\hline 10 years or more & 0.12 & 0.09 & 0.08 & 0.09 & 0.08 & 0.09 \\
\hline
\end{tabular}


Vignoli et al.: The positive impact of women's employment on divorce: Context, selection, or anticipation?

Table A-9: Parameter estimates for employment entry, Poland

\begin{tabular}{|c|c|c|c|c|c|c|c|c|}
\hline \multirow[b]{2}{*}{ Explanatory variable } & \multicolumn{3}{|c|}{$\begin{array}{l}\text { Single-process } \\
\text { model } \\
\text { (Model M1) }\end{array}$} & \multicolumn{3}{|c|}{$\begin{array}{l}\text { Multi-process model } \\
\text { with indicator of being } \\
\text { employed } \\
\text { (Model M2) }\end{array}$} & \multicolumn{2}{|c|}{$\begin{array}{l}\text { Multi-process model } \\
\text { with duration } \\
\text { dependence since } \\
\text { entry into employment } \\
\text { (Model M3) }\end{array}$} \\
\hline & Coeff. & & SE & Coeff. & & $\overline{\mathrm{SE}}$ & Coeff. & SE \\
\hline Intercept & -2.81 & $* \star *$ & 0.12 & -2.81 & *** & 0.13 & $-2.81^{* \star \star}$ & 0.13 \\
\hline \multicolumn{9}{|l|}{ Time since entering nonemployment } \\
\hline $0-0.5$ years (slope) & 1.34 & $* * *$ & 0.18 & 1.34 & $* \star \star$ & 0.19 & $1.34^{* \star *}$ & 0.19 \\
\hline $0.5-1$ years (slope) & -1.34 & *** & 0.12 & -1.34 & $* * *$ & 0.12 & $-1.34 * * *$ & 0.12 \\
\hline $1-3$ years (slope) & -0.16 & $* * *$ & 0.03 & -0.16 & $* * *$ & 0.03 & $-0.16^{* \star *}$ & 0.03 \\
\hline $3-5$ years (slope) & -0.18 & $* * *$ & 0.02 & -0.18 & *** & 0.02 & $-0.18^{* * *}$ & 0.02 \\
\hline$>5$ years (slope) & -0.06 & $\star * *$ & 0.01 & -0.06 & $* \star \star$ & 0.01 & $-0.06^{* * *}$ & 0.01 \\
\hline \multicolumn{9}{|l|}{ Age } \\
\hline 15-19 years (slope) & 1.01 & $* * *$ & 0.02 & 1.01 & 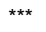 & 0.02 & $1.01 * \star *$ & 0.02 \\
\hline 20-24 years (slope) & 0.19 & $* * *$ & 0.01 & 0.19 & $* * *$ & 0.02 & $0.19^{* * *}$ & 0.02 \\
\hline $25-29$ years (slope) & -0.05 & $* * *$ & 0.01 & -0.05 & $* * *$ & 0.01 & $-0.05^{* * *}$ & 0.01 \\
\hline 30-39 years (slope) & 0.07 & $* * *$ & 0.01 & 0.07 & $* \star \star$ & 0.01 & $0.07^{* * *}$ & 0.01 \\
\hline 40-44 years (slope) & -0.09 & $* * *$ & 0.02 & -0.09 & $* \star *$ & 0.02 & $-0.09^{* * *}$ & 0.02 \\
\hline 45 or more years (slope) & -0.10 & $* * *$ & 0.02 & -0.10 & $* * *$ & 0.02 & $-0.10 * * *$ & 0.02 \\
\hline \multicolumn{9}{|l|}{ Calendar time } \\
\hline 1970-1989 (slope) & -0.02 & $\star * \star *$ & 0.00 & -0.02 & $* \star \star$ & 0.00 & $-0.02^{* \star *}$ & 0.00 \\
\hline 1990-1993 (slope) & -0.12 & $* * *$ & 0.02 & -0.12 & $* * *$ & 0.02 & $-0.12 * * *$ & 0.02 \\
\hline 1994-1997 (slope) & 0.01 & & 0.02 & 0.01 & & 0.02 & 0.01 & 0.02 \\
\hline 1998-1903 (slope) & -0.04 & *** & 0.01 & -0.04 & $* * *$ & 0.01 & $-0.04 * * *$ & 0.01 \\
\hline 2004-1907 (slope) & 0.17 & *** & 0.01 & 0.17 & $* * *$ & 0.01 & $0.17^{* * *}$ & 0.01 \\
\hline $2008-1911$ (slope) & -0.07 & $\star \star \star *$ & 0.02 & -0.07 & $* \star *$ & 0.02 & $-0.07^{* \star *}$ & 0.02 \\
\hline \multicolumn{9}{|c|}{ Age of the youngest child (duration since conception) } \\
\hline Pregnancy 0-6 months (slope) & -1.54 & *** & 0.36 & -1.54 & *** & 0.36 & -1.54 *** & 0.36 \\
\hline Pregnancy 6 months-child aged 6 months (slope) & -0.07 & & 0.15 & -0.07 & & 0.15 & -0.07 & 0.15 \\
\hline Child aged 6 months -3 years (slope) & 0.31 & *** & 0.03 & 0.31 & $* * *$ & 0.03 & $0.31^{* * *}$ & 0.03 \\
\hline Child aged $3-5$ years (slope) & 0.09 & *** & 0.03 & 0.09 & $* * *$ & 0.03 & $0.09^{* * *}$ & 0.03 \\
\hline Child aged over 5 years (slope) & 0.01 & ** & 0.01 & 0.01 & ** & 0.01 & $0.01 * \star$ & 0.01 \\
\hline \multicolumn{9}{|l|}{ Number of children (ref. = no children) } \\
\hline One & -0.41 & $* * *$ & 0.12 & -0.41 & $* * *$ & 0.12 & $-0.41 * \star *$ & 0.12 \\
\hline Two & -0.29 & *** & 0.04 & -0.29 & $* * *$ & 0.04 & $-0.29 * * *$ & 0.04 \\
\hline Three or more & -0.49 & *** & 0.06 & -0.50 & *** & 0.06 & $-0.50 * * *$ & 0.06 \\
\hline \multicolumn{9}{|l|}{ Mother's employment (ref. = no) } \\
\hline Yes & 0.15 & *** & 0.04 & 0.15 & $* \star *$ & 0.04 & $0.15^{\star \star \star}$ & 0.04 \\
\hline \multicolumn{9}{|c|}{ Parental education (ref. = no parent with higher education) } \\
\hline \multicolumn{9}{|l|}{ Order of nonemployment spell (ref. = first) } \\
\hline Second & -0.57 & $* * *$ & 0.13 & -0.58 & $* * *$ & 0.13 & -0.58 *** & 0.13 \\
\hline Third & -0.69 & *** & 0.14 & -0.70 & $* \star *$ & 0.14 & $-0.70^{* * *}$ & 0.14 \\
\hline Fourth or next & -0.96 & *** & 0.15 & -0.96 & $* * *$ & 0.15 & $-0.95 * * *$ & 0.15 \\
\hline \multicolumn{9}{|l|}{ Marital status (ref. = married) } \\
\hline Single & 0.15 & $* * *$ & 0.05 & 0.14 & $* * *$ & 0.05 & $0.15^{* \star *}$ & 0.05 \\
\hline Divorced & 0.26 & $* * *$ & 0.08 & 0.21 & $* *$ & 0.09 & & \\
\hline Divorce (intercept) & & & & & & & 0.26 ** & 0.11 \\
\hline Duration since divorce (slope) & & & & & & & -0.01 & 0.01 \\
\hline Widowed & 0.02 & & 0.14 & 0.01 & & 0.14 & 0.01 & 0.14 \\
\hline Cohabiting & 0.00 & & 0.05 & 0.00 & & 0.05 & 0.00 & 0.05 \\
\hline
\end{tabular}


Table A-9: (Continued)

\begin{tabular}{|c|c|c|c|c|c|c|c|c|}
\hline \multirow[b]{2}{*}{ Explanatory variable } & \multicolumn{3}{|c|}{$\begin{array}{l}\text { Single-process } \\
\text { model }\end{array}$} & \multicolumn{3}{|c|}{$\begin{array}{l}\text { Multi-process model } \\
\text { with indicator of being } \\
\text { employed } \\
\text { (Model M2) }\end{array}$} & \multicolumn{2}{|c|}{$\begin{array}{l}\text { Multi-process model } \\
\text { with duration } \\
\text { dependence since } \\
\text { entry into employment } \\
\text { (Model M3) } \\
\end{array}$} \\
\hline & Coeff. & & SE & Coeff. & & SE & Coeff. & SE \\
\hline \multicolumn{9}{|c|}{ Educational level (ref. = tertiary) } \\
\hline Secondary & -0.57 & $* * *$ & 0.05 & -0.57 & $* * *$ & 0.05 & $-0.57^{* \star *}$ & 0.05 \\
\hline Vocational & -0.89 & $\star \star \star *$ & 0.05 & -0.89 & 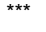 & 0.06 & $-0.89 * \star *$ & 0.06 \\
\hline Primary & -1.59 & *** & 0.07 & -1.59 & $* * *$ & 0.07 & $-1.59^{* * *}$ & 0.07 \\
\hline In education & -2.17 & *** & 0.05 & -2.17 & $* * *$ & 0.05 & $-2.17^{\star \star *}$ & 0.05 \\
\hline \multicolumn{9}{|c|}{ Work experience $($ ref. $=$ none $)$} \\
\hline $0-3$ years & -0.49 & $* * *$ & 0.13 & -0.49 & $* * *$ & 0.13 & $-0.49 * * *$ & 0.13 \\
\hline $3-6$ years & -1.04 & $\star \star \star *$ & 0.14 & -1.05 & $* \star \star$ & 0.14 & $-1.05^{* \star *}$ & 0.14 \\
\hline $6-10$ years & -1.32 & $* * *$ & 0.15 & -1.34 & $\star \star \star *$ & 0.15 & $-1.34^{* \star *}$ & 0.15 \\
\hline 10 years or more & -1.79 & *** & 0.16 & -1.81 & $* * *$ & 0.17 & $-1.81^{* * *}$ & 0.17 \\
\hline
\end{tabular}


Vignoli et al.: The positive impact of women's employment on divorce: Context, selection, or anticipation?

Table A-10: Parameter estimates for employment exit, Germany

\begin{tabular}{|c|c|c|c|c|c|c|c|c|c|}
\hline \multirow[b]{2}{*}{ Explanatory variable } & \multicolumn{3}{|c|}{$\begin{array}{l}\text { Single-process } \\
\text { model }\end{array}$} & \multicolumn{3}{|c|}{ 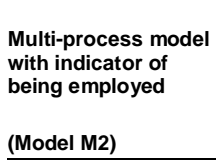 } & \multicolumn{3}{|c|}{$\begin{array}{l}\text { Multi-process model } \\
\text { with duration } \\
\text { dependence since } \\
\text { entry into } \\
\text { employment } \\
\text { (Model M3) }\end{array}$} \\
\hline & Coeff. & & SE & Coeff. & & SE & Coeff. & & SE \\
\hline Intercept & -5.07 & $* * *$ & 0.67 & -4.93 & $* * *$ & 0.74 & -4.91 & $* * *$ & 0.74 \\
\hline \multicolumn{10}{|l|}{ Time since entering employment } \\
\hline $0-0.5$ years (slope) & 3.47 & $* * *$ & 1.04 & 3.42 & $* \star *$ & 1.14 & 3.41 & $* * *$ & 1.14 \\
\hline $0.5-1$ years (slope) & 0.34 & & 0.34 & 0.36 & & 0.37 & 0.36 & & 0.37 \\
\hline $1-3$ years (slope) & 0.13 & * & 0.07 & 0.13 & * & 0.08 & 0.13 & * & 0.08 \\
\hline $3-5$ years (slope) & -0.29 & $* \star *$ & 0.07 & -0.28 & $* \star *$ & 0.08 & -0.28 & $* \star *$ & 0.08 \\
\hline$>5$ years (slope) & -0.05 & $* * *$ & 0.02 & -0.05 & *** & 0.02 & -0.05 & $* * *$ & 0.02 \\
\hline \multicolumn{10}{|l|}{ Age } \\
\hline $15-19$ years (slope) & -0.07 & & 0.10 & -0.07 & & 0.10 & -0.07 & & 0.10 \\
\hline 20-24 years (slope) & -0.09 & $* *$ & 0.04 & -0.12 & $* \star \star$ & 0.04 & -0.12 & $* * *$ & 0.04 \\
\hline $25-29$ years (slope) & -0.04 & & 0.03 & -0.08 & $\star \star *$ & 0.04 & -0.07 & ** & 0.04 \\
\hline 30-39 years (slope) & -0.07 & $* * *$ & 0.02 & -0.10 & $* * *$ & 0.02 & -0.10 & $* * *$ & 0.02 \\
\hline 40-44 years (slope) & -0.06 & & 0.05 & -0.08 & & 0.05 & -0.08 & & 0.06 \\
\hline 45 or more years (slope) & -0.09 & & 0.06 & -0.12 & * & 0.07 & -0.12 & * & 0.07 \\
\hline \multicolumn{10}{|l|}{ Calendar time } \\
\hline 1970-1989 (slope) & 0.05 & $* \star *$ & 0.02 & 0.05 & $* * *$ & 0.02 & 0.05 & $* * *$ & 0.02 \\
\hline 1990-1993 (slope) & 0.02 & & 0.04 & 0.02 & & 0.04 & 0.02 & & 0.04 \\
\hline 1994-1997 (slope) & 0.05 & & 0.04 & 0.06 & & 0.04 & 0.06 & & 0.04 \\
\hline 1998-1903 (slope) & 0.03 & & 0.03 & 0.03 & & 0.03 & 0.03 & & 0.03 \\
\hline 2004-1907 (slope) & 0.01 & & 0.05 & 0.01 & & 0.06 & 0.01 & & 0.06 \\
\hline 2008-1911 (slope) & 0.23 & & 0.27 & 0.23 & & 0.27 & 0.23 & & 0.27 \\
\hline \multicolumn{10}{|l|}{ Age of the youngest child (duration since conception) } \\
\hline Pregnancy 0-6 months (slope) & 5.81 & $* \star *$ & 0.47 & 5.81 & $* \star *$ & 0.50 & 5.81 & $* \star *$ & 0.50 \\
\hline Pregnancy 6 months-child aged 6 months (slope) & -2.83 & *** & 0.25 & -2.85 & $\star \star \star *$ & 0.26 & -2.85 & $* * *$ & 0.27 \\
\hline Child aged 6 months -3 years (slope) & -0.27 & $* * *$ & 0.10 & -0.26 & ** & 0.10 & -0.26 & ** & 0.10 \\
\hline Child aged $3-5$ years (slope) & 0.09 & & 0.11 & 0.09 & & 0.11 & 0.10 & & 0.11 \\
\hline Child aged over 5 years (slope) & -0.01 & & 0.02 & -0.01 & & 0.02 & -0.01 & & 0.02 \\
\hline \multicolumn{10}{|l|}{ Number of children (ref. = no children) } \\
\hline One & -0.16 & & 0.22 & -0.16 & & 0.23 & -0.16 & & 0.23 \\
\hline Two & -0.42 & $* \star *$ & 0.11 & -0.41 & *** & 0.12 & -0.41 & $* * *$ & 0.12 \\
\hline Three or more & -0.27 & * & 0.15 & -0.24 & & 0.17 & -0.24 & & 0.17 \\
\hline \multicolumn{10}{|l|}{ Mother's employment (ref. = no) } \\
\hline Yes & -0.45 & & 0.37 & -0.41 & & 0.41 & -0.41 & & 0.41 \\
\hline \multicolumn{10}{|c|}{ Parental education (ref. = no parent with higher education) } \\
\hline At least one parent with tertiary education & 0.09 & & 0.12 & 0.12 & & 0.12 & 0.12 & & 0.12 \\
\hline \multicolumn{10}{|l|}{ Order of employment spell (ref. = first) } \\
\hline Second & -0.33 & & 0.20 & -0.09 & & 0.22 & -0.08 & & 0.22 \\
\hline Third & -0.64 & ** & 0.31 & -0.27 & & 0.33 & -0.25 & & 0.33 \\
\hline Fourth or next & -0.90 & ** & 0.40 & -0.41 & & 0.44 & -0.39 & & 0.45 \\
\hline \multicolumn{10}{|l|}{ Marital status (ref. = married) } \\
\hline Single & -0.11 & & 0.10 & -0.13 & & 0.10 & -0.13 & & 0.10 \\
\hline Divorced & 0.24 & & 0.16 & 0.15 & & 0.21 & & & \\
\hline Divorce (intercept) & & & & & & & 0.06 & & 0.27 \\
\hline Duration since divorce (slope) & & & & & & & 0.02 & & 0.04 \\
\hline Widowed & 1 & & 1 & 1 & & 1 & 1 & & 1 \\
\hline
\end{tabular}


Table A-10: (Continued)

\begin{tabular}{|c|c|c|c|c|c|c|c|c|c|}
\hline \multirow[b]{2}{*}{ Explanatory variable } & \multicolumn{3}{|c|}{$\begin{array}{l}\text { Single-process } \\
\text { model }\end{array}$} & \multicolumn{3}{|c|}{$\begin{array}{l}\text { Multi-process model } \\
\text { with indicator of } \\
\text { being employed } \\
\text { (Model M2) }\end{array}$} & \multicolumn{3}{|c|}{$\begin{array}{l}\text { Multi-process mode } \\
\text { with duration } \\
\text { dependence since } \\
\text { entry into } \\
\text { employment } \\
\text { (Model M3) }\end{array}$} \\
\hline & \multicolumn{2}{|c|}{ Coeff. } & \multirow[t]{2}{*}{ SE } & \multicolumn{2}{|c|}{ Coeff. } & \multirow[t]{2}{*}{ SE } & \multicolumn{2}{|c|}{ Coeff. } & \multirow[t]{2}{*}{ SE } \\
\hline Educational level (ref. = & & & & & & & & & \\
\hline Secondary & 0.24 & * & 0.13 & 0.24 & * & 0.14 & 0.24 & * & 0.14 \\
\hline Vocational/primary & 0.58 & $* * *$ & 0.18 & 0.64 & *** & 0.19 & 0.63 & *** & 0.19 \\
\hline In education & 0.91 & $* * *$ & 0.16 & 1.01 & $* * \star$ & 0.17 & 1.01 & 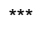 & 0.17 \\
\hline \multicolumn{10}{|c|}{ Work experience $($ ref. $=$ none) } \\
\hline $0-3$ years (slope) & 0.02 & & 0.08 & 0.02 & & 0.09 & 0.02 & & 0.09 \\
\hline 3-6 years (slope) & 0.18 & $* * *$ & 0.06 & 0.20 & $* \star *$ & 0.07 & 0.20 & *** & 0.07 \\
\hline $6-10$ years (slope) & 0.08 & * & 0.04 & 0.09 & ** & 0.04 & 0.09 & ** & 0.04 \\
\hline 10 years or more (slope) & 0.07 & $* \star *$ & 0.03 & 0.09 & 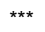 & 0.03 & 0.09 & $* \star \star$ & 0.03 \\
\hline
\end{tabular}


Vignoli et al.: The positive impact of women's employment on divorce: Context, selection, or anticipation?

Table A-11: Parameter estimates for employment exit, Hungary

\begin{tabular}{|c|c|c|c|c|c|c|c|c|c|}
\hline \multirow[b]{2}{*}{ Explanatory variable } & \multicolumn{3}{|c|}{$\begin{array}{l}\text { Single-process } \\
\text { model }\end{array}$} & \multicolumn{3}{|c|}{$\begin{array}{l}\text { Multi-process model } \\
\text { with indicator of } \\
\text { being employed } \\
\text { (Model M2) }\end{array}$} & \multicolumn{3}{|c|}{$\begin{array}{l}\text { Multi-process model } \\
\text { with duration } \\
\text { dependence since } \\
\text { entry into } \\
\text { employment } \\
\text { (Model M3) }\end{array}$} \\
\hline & Coeff. & & SE & Coeff. & & SE & Coeff. & & SE \\
\hline Intercept & -5.07 & 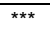 & 0.30 & -5.04 & $* \star \star \star *$ & 0.32 & -5.03 & 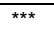 & 0.32 \\
\hline \multicolumn{10}{|l|}{ Time since entering employment } \\
\hline $0-0.5$ years (slope) & 3.30 & 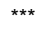 & 0.48 & 3.31 & $* \star *$ & 0.50 & 3.31 & $* \star *$ & 0.50 \\
\hline $0.5-1$ years (slope) & 0.10 & & 0.17 & 0.09 & & 0.18 & 0.10 & & 0.18 \\
\hline $1-3$ years (slope) & 0.41 & $* \star *$ & 0.04 & 0.41 & $\star \star * *$ & 0.04 & 0.41 & $* * *$ & 0.04 \\
\hline $3-5$ years (slope) & -0.30 & $* \star *$ & 0.03 & -0.31 & $\star \star * *$ & 0.03 & -0.30 & $* * *$ & 0.03 \\
\hline$>5$ years (slope) & -0.02 & $\star * *$ & 0.01 & -0.02 & $* *$ & 0.01 & -0.02 & $\star *$ & 0.01 \\
\hline \multicolumn{10}{|l|}{ Age } \\
\hline $15-19$ years (slope) & -0.07 & & 0.06 & -0.07 & & 0.06 & -0.07 & & 0.06 \\
\hline 20-24 years (slope) & -0.09 & $* \star \star$ & 0.02 & -0.09 & $* * *$ & 0.02 & -0.09 & $* * *$ & 0.02 \\
\hline $25-29$ years (slope) & -0.04 & $\star *$ & 0.02 & -0.04 & $* *$ & 0.02 & -0.04 & $\star *$ & 0.02 \\
\hline 30-39 years (slope) & -0.01 & & 0.01 & -0.01 & & 0.01 & -0.01 & & 0.01 \\
\hline 40-44 years (slope) & 0.02 & & 0.02 & 0.02 & & 0.02 & 0.02 & & 0.02 \\
\hline 45 or more years (slope) & 0.03 & & 0.02 & 0.03 & & 0.02 & 0.03 & & 0.02 \\
\hline \multicolumn{10}{|l|}{ Calendar time } \\
\hline 1970-1989 (slope) & 0.05 & $* \star *$ & 0.01 & 0.05 & $* * *$ & 0.01 & 0.05 & $* * *$ & 0.01 \\
\hline 1990-1993 (slope) & 0.04 & $\star \star$ & 0.02 & 0.04 & * & 0.02 & 0.04 & * & 0.02 \\
\hline 1994-1997 (slope) & 0.02 & & 0.02 & 0.02 & & 0.02 & 0.02 & & 0.02 \\
\hline 1998-2003 (slope) & 0.04 & $* \star *$ & 0.01 & 0.04 & *** & 0.01 & 0.04 & $* * *$ & 0.01 \\
\hline 2004-2007 (slope) & 0.02 & & 0.02 & 0.02 & & 0.02 & 0.02 & & 0.02 \\
\hline 2008-2011 (slope) & 1.74 & 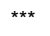 & 0.11 & 1.74 & $\star \star \star *$ & 0.11 & 1.74 & $* * *$ & 0.11 \\
\hline \multicolumn{10}{|c|}{ Age of the youngest child (duration since conception) } \\
\hline Pregnancy 0-6 months (slope) & 5.13 & $\star \star \star *$ & 0.30 & 5.13 & $\star \star \star *$ & 0.31 & 5.13 & $* \star *$ & 0.31 \\
\hline Pregnancy 6 months-child aged 6months (slope) & -4.07 & $* \star \star$ & 0.16 & -4.07 & $\star \star \star *$ & 0.16 & -4.07 & $* * *$ & 0.16 \\
\hline Child aged 6 months -3 years (slope) & 1.10 & $* * *$ & 0.04 & 1.10 & $* * *$ & 0.04 & 1.10 & $* \star *$ & 0.04 \\
\hline Child aged $3-5$ years (slope) & -0.99 & 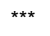 & 0.04 & -0.99 & $\star \star \star *$ & 0.04 & -0.99 & $* * *$ & 0.04 \\
\hline Child aged over 5 years (slope) & 0.00 & & 0.01 & 0.00 & & 0.01 & 0.00 & & 0.01 \\
\hline \multicolumn{10}{|l|}{ Number of children (ref. = no children) } \\
\hline One & -0.31 & ** & 0.13 & -0.31 & $* *$ & 0.14 & -0.31 & ** & 0.14 \\
\hline Two & -0.28 & $* * *$ & 0.06 & -0.28 & $* * *$ & 0.06 & -0.28 & $* \star * *$ & 0.06 \\
\hline Three or more & -0.24 & 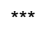 & 0.08 & -0.24 & $\star \star \star *$ & 0.08 & -0.24 & $* * *$ & 0.08 \\
\hline \multicolumn{10}{|l|}{ Mother's employment (ref. = no) } \\
\hline Yes & 0.00 & & 0.00 & 0.00 & & 0.00 & 0.00 & & 0.00 \\
\hline \multicolumn{10}{|c|}{ Parental education (ref. = no parent with higher education) } \\
\hline At least one parent with tertiary education & -0.02 & & 0.07 & -0.02 & & 0.07 & -0.02 & & 0.07 \\
\hline \multicolumn{10}{|l|}{ Order of employment spell (ref. = first) } \\
\hline Second & 0.11 & & 0.08 & 0.11 & & 0.08 & 0.11 & & 0.08 \\
\hline Third & 0.05 & & 0.12 & 0.06 & & 0.13 & 0.06 & & 0.13 \\
\hline Fourth or next & 0.08 & & 0.17 & 0.08 & & 0.18 & 0.09 & & 0.19 \\
\hline \multicolumn{10}{|l|}{ Marital status (ref. = married) } \\
\hline Single & -0.03 & & 0.06 & -0.04 & & 0.06 & -0.04 & & 0.06 \\
\hline Divorced & 0.05 & & 0.07 & 0.01 & & 0.08 & & & \\
\hline Divorce (intercept) & & & & & & & -0.08 & & 0.11 \\
\hline Duration since divorce (slope) & & & & & & & 0.01 & & 0.01 \\
\hline Widowed & 0.08 & & 0.13 & 0.08 & & 0.14 & 0.08 & & 0.14 \\
\hline
\end{tabular}


Table A-11: (Continued)

\begin{tabular}{|c|c|c|c|c|c|c|c|c|c|}
\hline \multirow[b]{2}{*}{ Explanatory variable } & \multicolumn{3}{|c|}{$\begin{array}{l}\text { Single-process } \\
\text { model }\end{array}$} & \multicolumn{3}{|c|}{$\begin{array}{l}\text { Multi-process model } \\
\text { with indicator of } \\
\text { being employed } \\
\text { (Model M2) }\end{array}$} & \multicolumn{3}{|c|}{$\begin{array}{l}\text { Multi-process model } \\
\text { with duration } \\
\text { dependence since } \\
\text { entry into } \\
\text { employment } \\
\text { (Model M3) }\end{array}$} \\
\hline & Coeff. & & SE & Coeff. & & SE & Coeff. & & SE \\
\hline \multicolumn{10}{|c|}{ Educational level (ref. = tertiary) } \\
\hline Secondary & 0.34 & $* * *$ & 0.06 & 0.32 & $* \star * *$ & 0.06 & 0.32 & $* * *$ & 0.06 \\
\hline Vocational/primary & 0.58 & *** & 0.08 & 0.57 & $* \star *$ & 0.08 & 0.57 & $* * *$ & 0.08 \\
\hline In education & 0.42 & $* \star *$ & 0.07 & 0.41 & $* \star *$ & 0.07 & 0.41 & $* \star *$ & 0.07 \\
\hline \multicolumn{10}{|c|}{ Work experience $($ ref. $=$ none $)$} \\
\hline $0-3$ years (slope) & -0.33 & $* \star *$ & 0.04 & -0.33 & $\star * *$ & 0.04 & -0.33 & $* \star *$ & 0.04 \\
\hline 3-6 years (slope) & 0.11 & $* * *$ & 0.03 & 0.12 & $* * *$ & 0.03 & 0.12 & $* * *$ & 0.03 \\
\hline $6-10$ years (slope) & 0.01 & & 0.02 & 0.01 & & 0.02 & 0.01 & & 0.02 \\
\hline 10 years or more (slope) & 0.00 & & 0.01 & 0.00 & & 0.01 & 0.00 & & 0.01 \\
\hline
\end{tabular}


Vignoli et al.: The positive impact of women's employment on divorce: Context, selection, or anticipation?

Table A-12: Parameter estimates for employment exit, Italy

\begin{tabular}{|c|c|c|c|c|c|c|c|c|c|}
\hline \multirow[b]{2}{*}{ Explanatory variable } & \multicolumn{3}{|c|}{ Single-process model } & \multicolumn{3}{|c|}{$\begin{array}{l}\text { Multi-process model } \\
\text { with indicator of } \\
\text { being employed } \\
\text { (Model M2) }\end{array}$} & \multicolumn{3}{|c|}{$\begin{array}{l}\text { Multi-process model } \\
\text { with duration } \\
\text { dependence since } \\
\text { entry into } \\
\text { employment } \\
\text { (Model M3) }\end{array}$} \\
\hline & Coeff. & & SE & Coeff. & & SE & Coeff. & & SE \\
\hline Intercept & -2.88 & $* \star * *$ & 0.12 & -2.96 & 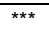 & 0.13 & -2.97 & $* * *$ & 0.09 \\
\hline \multicolumn{10}{|l|}{ Time since entering employment } \\
\hline $0-0.5$ years (slope) & 0.85 & $\star \star \star *$ & 0.12 & 0.85 & $* \star *$ & 0.13 & 0.85 & $* * *$ & 0.10 \\
\hline $0.5-1$ years (slope) & -1.14 & $\star \star \star *$ & 0.09 & -1.14 & $* * *$ & 0.09 & -1.14 & $* \star *$ & 0.09 \\
\hline $1-3$ years (slope) & -0.06 & ** & 0.03 & -0.06 & ** & 0.03 & -0.06 & *** & 0.03 \\
\hline $3-5$ years (slope) & -0.02 & & 0.03 & -0.02 & & 0.03 & -0.02 & $* * *$ & 0.02 \\
\hline > 5 years (slope) & -0.01 & ** & 0.01 & -0.01 & $* *$ & 0.01 & -0.01 & $* * *$ & 0.00 \\
\hline \multicolumn{10}{|l|}{ Age } \\
\hline 15-19 years (slope) & 0.13 & *** & 0.02 & 0.13 & $* \star * *$ & 0.02 & 0.13 & $* * *$ & 0.02 \\
\hline 20-24 years (slope) & -0.07 & $* \star *$ & 0.01 & -0.05 & $* * *$ & 0.01 & -0.05 & $* * *$ & 0.01 \\
\hline 25-29 years (slope) & -0.05 & 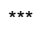 & 0.01 & -0.04 & $* \star \star$ & 0.01 & -0.04 & 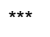 & 0.01 \\
\hline 30-39 years (slope) & -0.09 & $* * *$ & 0.01 & -0.08 & $* \star *$ & 0.01 & -0.08 & $\star *$ & 0.01 \\
\hline 40-44 years (slope) & -0.05 & $* \star *$ & 0.02 & -0.04 & $* *$ & 0.02 & -0.04 & * & 0.02 \\
\hline 45 or more years (slope) & -0.05 & $* \star *$ & 0.02 & -0.04 & $* *$ & 0.02 & -0.04 & $* * *$ & 0.02 \\
\hline \multicolumn{10}{|l|}{ Calendar time } \\
\hline 1970-1989 (slope) & 0.02 & $* \star *$ & 0.00 & 0.02 & $* * *$ & 0.00 & 0.02 & $* * *$ & 0.00 \\
\hline 1990-1993 (slope) & 0.02 & & 0.01 & 0.02 & & 0.01 & 0.02 & $* \star *$ & 0.01 \\
\hline 1994-1997 (slope) & 0.05 & $* * *$ & 0.01 & 0.05 & $* \star * *$ & 0.01 & 0.05 & $* * *$ & 0.01 \\
\hline 1998-2003 (slope) & 0.02 & * & 0.01 & 0.02 & * & 0.01 & 0.02 & & 0.01 \\
\hline 2004-2007 (slope) & 0.08 & $* \star *$ & 0.01 & 0.08 & $* \star *$ & 0.01 & 0.08 & $* \star *$ & 0.01 \\
\hline 2008-2011 (slope) & -0.07 & * & 0.04 & -0.07 & * & 0.04 & -0.07 & $* \star *$ & 0.04 \\
\hline \multicolumn{10}{|c|}{ Age of the youngest child (duration since conception) } \\
\hline Pregnancy 0-6 months (slope) & 1.95 & *** & 0.28 & 1.95 & $* \star *$ & 0.28 & 1.95 & $* * *$ & 0.44 \\
\hline Pregnancy 6 months-child aged 6 months (slope) & -0.85 & *** & 0.11 & -0.86 & $* \star *$ & 0.11 & -0.86 & $* * *$ & 0.17 \\
\hline Child aged 6 months -3 years (slope) & -0.25 & $* \star *$ & 0.04 & -0.25 & $* \star *$ & 0.04 & -0.25 & $* * *$ & 0.03 \\
\hline Child aged $3-5$ years (slope) & 0.12 & $* \star *$ & 0.04 & 0.12 & $* \star *$ & 0.04 & 0.12 & & 0.03 \\
\hline Child aged over 5 years (slope) & 0.01 & ** & 0.01 & 0.01 & $\star *$ & 0.01 & 0.01 & ** & 0.01 \\
\hline \multicolumn{10}{|l|}{ Number of children (ref. = no children) } \\
\hline One & 0.10 & & 0.12 & 0.10 & & 0.12 & 0.10 & $* \star *$ & 0.16 \\
\hline Two & 0.01 & & 0.04 & -0.01 & & 0.04 & -0.01 & $* * *$ & 0.04 \\
\hline Three or more & 0.14 & ** & 0.07 & 0.11 & & 0.07 & 0.10 & $* * *$ & 0.06 \\
\hline \multicolumn{10}{|l|}{ Mother's employment (ref. = no) } \\
\hline Yes & -0.02 & & 0.03 & 0.01 & & 0.03 & 0.01 & $\star \star * *$ & 0.08 \\
\hline \multicolumn{10}{|c|}{ Parental education (ref. = no parent with higher education) } \\
\hline At least one parent with tertiary education & 0.07 & & 0.06 & 0.04 & & 0.06 & 0.04 & $* * *$ & 0.04 \\
\hline \multicolumn{10}{|l|}{ Order of employment spell (ref. = first) } \\
\hline Second & 0.21 & *** & 0.05 & 0.15 & $* * *$ & 0.05 & 0.15 & $* * *$ & 0.07 \\
\hline Third & 0.19 & $* *$ & 0.08 & 0.09 & & 0.08 & 0.09 & $* \star *$ & 0.04 \\
\hline Fourth or next & 0.23 & ** & 0.11 & 0.10 & & 0.12 & 0.09 & & 0.12 \\
\hline \multicolumn{10}{|l|}{ Marital status (ref. = married) } \\
\hline Single & 0.10 & $* * *$ & 0.04 & 0.11 & $* * *$ & 0.04 & 0.11 & $* * *$ & 0.05 \\
\hline Divorced & 0.17 & $* \star *$ & 0.05 & 0.17 & 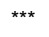 & 0.06 & & & \\
\hline Divorce (intercept) & & & & & & & 0.23 & $* \star *$ & 0.08 \\
\hline Duration since divorce (slope) & & & & & & & 0.00 & & 0.01 \\
\hline Widowed & 0.41 & ** & 0.18 & 0.41 & ** & 0.19 & 0.40 & $* \star *$ & 0.04 \\
\hline
\end{tabular}


Table A-12: (Continued)

\begin{tabular}{|c|c|c|c|c|c|c|c|c|}
\hline \multirow[b]{2}{*}{ Explanatory variable } & \multicolumn{2}{|c|}{ Single-process model } & \multicolumn{3}{|c|}{$\begin{array}{l}\text { Multi-process model } \\
\text { with indicator of } \\
\text { being employed } \\
\text { (Model M2) }\end{array}$} & \multicolumn{3}{|c|}{$\begin{array}{l}\text { Multi-process mode } \\
\text { with duration } \\
\text { dependence since } \\
\text { entry into } \\
\text { employment } \\
\text { (Model M3) }\end{array}$} \\
\hline & Coeff. & SE & Coeff. & & SE & Coeff. & & SE \\
\hline \multicolumn{9}{|c|}{ Educational level (ref. = tertiary) } \\
\hline Secondary & $-0.11^{\star *}$ & 0.04 & -0.11 & ** & 0.05 & -0.11 & $\star \star \star *$ & 0.07 \\
\hline Vocational & 0.08 & 0.06 & 0.10 & & 0.06 & 0.10 & $\star \star \star *$ & 0.07 \\
\hline Primary & $0.24 * * *$ & 0.05 & 0.23 & $\star * *$ & 0.05 & 0.23 & $* \star *$ & 0.08 \\
\hline In education & $0.58^{* \star *}$ & 0.05 & 0.56 & *** & 0.05 & 0.56 & & 0.09 \\
\hline \multicolumn{9}{|c|}{ Work experience $($ ref. $=$ none $)$} \\
\hline $0-3$ years (slope) & $-0.13^{* \star *}$ & 0.03 & -0.13 & $* * *$ & 0.03 & -0.13 & $* \star *$ & 0.03 \\
\hline 3-6 years (slope) & $-0.06^{* * *}$ & 0.02 & -0.07 & $* * *$ & 0.02 & -0.07 & $* * *$ & 0.14 \\
\hline $6-10$ years (slope) & $0.03 * *$ & 0.01 & 0.02 & & 0.01 & 0.02 & $* * *$ & 0.07 \\
\hline 10 years or more (slope) & 0.01 & 0.01 & 0.00 & & 0.01 & 0.00 & 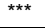 & 0.07 \\
\hline
\end{tabular}


Vignoli et al.: The positive impact of women's employment on divorce: Context, selection, or anticipation?

\section{Table A-13: Parameter estimates for employment exit, Poland}

\begin{tabular}{|c|c|c|c|c|c|c|c|c|c|}
\hline \multirow[b]{2}{*}{ Explanatory variable } & \multicolumn{3}{|c|}{ Single-process model } & \multicolumn{3}{|c|}{$\begin{array}{l}\text { Multi-process model } \\
\text { with indicator of } \\
\text { being employed } \\
\text { (Model M2) }\end{array}$} & \multicolumn{3}{|c|}{$\begin{array}{l}\text { Multi-process model } \\
\text { with duration } \\
\text { dependence since } \\
\text { entry into } \\
\text { employment } \\
\text { (Model M3) }\end{array}$} \\
\hline & Coeff. & & SE & Coeff. & & SE & Coeff. & & SE \\
\hline Intercept & -7.09 & $\star \star * *$ & 0.28 & -7.07 & $* \star \star$ & 0.28 & -7.07 & $\star * \star *$ & 0.28 \\
\hline \multicolumn{10}{|l|}{ Time since entering employment } \\
\hline $0-0.5$ years (slope) & 1.93 & $* \star *$ & 0.21 & 1.94 & $\star \star \star *$ & 0.21 & 1.94 & *** & 0.21 \\
\hline $0.5-1$ years (slope) & -0.68 & $* \star *$ & 0.12 & -0.68 & $\star \star *$ & 0.13 & -0.68 & $* * *$ & 0.13 \\
\hline $1-3$ years (slope) & -0.11 & *** & 0.04 & -0.11 & $\star \star * *$ & 0.04 & -0.11 & $* * *$ & 0.04 \\
\hline $3-5$ years (slope) & -0.13 & $\star * *$ & 0.03 & -0.13 & $\star \star *$ & 0.04 & -0.13 & $* * *$ & 0.04 \\
\hline$>5$ years $($ slope $)$ & -0.02 & $* * *$ & 0.01 & -0.02 & $\star \star \star$ & 0.01 & -0.02 & $\star \star *$ & 0.01 \\
\hline \multicolumn{10}{|l|}{ Age } \\
\hline $15-19$ years (slope) & 0.29 & $* * *$ & 0.06 & 0.29 & $\star \star \star *$ & 0.06 & 0.29 & $* * *$ & 0.06 \\
\hline 20-24 years (slope) & -0.12 & $* * *$ & 0.02 & -0.12 & $* * *$ & 0.02 & -0.12 & $* * *$ & 0.02 \\
\hline 25-29 years (slope) & -0.07 & $\star \star * *$ & 0.01 & -0.07 & $\star \star \star ~$ & 0.02 & -0.07 & $* * *$ & 0.02 \\
\hline 30-39 years (slope) & -0.07 & $\star * *$ & 0.01 & -0.07 & $\star \star *$ & 0.01 & -0.07 & $* * *$ & 0.01 \\
\hline 40-44 years (slope) & -0.04 & $\star *$ & 0.02 & -0.04 & $\star \star$ & 0.02 & -0.04 & $\star *$ & 0.02 \\
\hline 45 or more years (slope) & 0.03 & * & 0.02 & 0.03 & & 0.02 & 0.03 & & 0.02 \\
\hline \multicolumn{10}{|l|}{ Calendar time } \\
\hline 1970-1989 (slope) & 0.10 & $* * *$ & 0.01 & 0.10 & $\star * *$ & 0.01 & 0.10 & $* * *$ & 0.01 \\
\hline 1990-1993 (slope) & 0.15 & $* \star *$ & 0.02 & 0.15 & $\star \star *$ & 0.02 & 0.15 & $* * *$ & 0.02 \\
\hline 1994-1997 (slope) & 0.04 & ** & 0.02 & 0.04 & $\star *$ & 0.02 & 0.04 & $* *$ & 0.02 \\
\hline 1998-2003 (slope) & 0.04 & $* * *$ & 0.01 & 0.04 & $\star \star \star *$ & 0.01 & 0.04 & $* * *$ & 0.01 \\
\hline 2004-2007 (slope) & 0.06 & $* * *$ & 0.02 & 0.06 & $\star * *$ & 0.02 & 0.06 & $* * *$ & 0.02 \\
\hline 2008-2011 (slope) & 0.21 & *** & 0.03 & 0.21 & $\star \star * *$ & 0.03 & 0.21 & $\star \star * *$ & 0.03 \\
\hline \multicolumn{10}{|c|}{ Age of the youngest child (duration since conception) } \\
\hline Pregnancy 0-6 months (slope) & 1.06 & *** & 0.35 & 1.06 & $\star \star *$ & 0.35 & 1.06 & *** & 0.35 \\
\hline Pregnancy 6 months-child aged 6 months (slope) & -0.47 & *** & 0.14 & -0.47 & $\star * *$ & 0.14 & -0.47 & *** & 0.14 \\
\hline Child aged 6 months -3 years (slope) & 0.16 & *** & 0.03 & 0.16 & $\star \star \star$ & 0.03 & 0.16 & $* * *$ & 0.03 \\
\hline Child aged $3-5$ years (slope) & -0.19 & $\star \star * *$ & 0.03 & -0.19 & $\star \star *$ & 0.04 & -0.19 & $* \star *$ & 0.04 \\
\hline Child aged over 5 years (slope) & -0.01 & & 0.01 & -0.01 & & 0.01 & -0.01 & & 0.01 \\
\hline \multicolumn{10}{|l|}{ Number of children (ref. = no children) } \\
\hline One & -0.14 & & 0.13 & -0.14 & & 0.13 & -0.14 & & 0.13 \\
\hline Two & 0.08 & * & 0.05 & 0.08 & * & 0.05 & 0.08 & * & 0.05 \\
\hline Three or more & 0.06 & & 0.07 & 0.07 & & 0.07 & 0.07 & & 0.07 \\
\hline \multicolumn{10}{|l|}{ Mother's employment (ref. = no) } \\
\hline Yes & -0.09 & & 0.05 & -0.09 & & 0.05 & -0.09 & & 0.05 \\
\hline \multicolumn{10}{|c|}{ Parental education (ref. = no parent with higher education) } \\
\hline At least one parent with tertiary education & -0.01 & & 0.08 & 0.00 & & 0.08 & 0.00 & & 0.08 \\
\hline \multicolumn{10}{|l|}{ Order of employment spell (ref. = first) } \\
\hline Second & -0.30 & *** & 0.08 & -0.28 & *** & 0.09 & -0.28 & $* * *$ & 0.09 \\
\hline Third & -0.44 & $* * *$ & 0.13 & -0.42 & $\star \star \star$ & 0.14 & -0.42 & $\star \star *$ & 0.14 \\
\hline Fourth or next & -0.76 & $* * *$ & 0.16 & -0.74 & $\star * *$ & 0.18 & -0.74 & $\star \star * *$ & 0.18 \\
\hline \multicolumn{10}{|l|}{ Marital status (ref. = married) } \\
\hline Single & 0.22 & $\star \star * *$ & 0.07 & 0.21 & $\star \star \star *$ & 0.07 & 0.22 & $* * *$ & 0.07 \\
\hline Divorced & 0.29 & $\star * *$ & 0.09 & 0.10 & & 0.10 & & & \\
\hline Divorce (intercept) & & & & & & & 0.12 & & 0.11 \\
\hline Duration since divorce (slope) & & & & & & & 0.00 & & 0.01 \\
\hline Widowed & 0.29 & ** & 0.13 & 0.29 & ** & 0.13 & 0.29 & $\star *$ & 0.13 \\
\hline Cohabiting & 0.12 & * & 0.06 & 0.12 & * & 0.06 & 0.12 & * & 0.06 \\
\hline
\end{tabular}


Table A-13: (Continued)

\begin{tabular}{|c|c|c|c|c|c|c|c|c|c|}
\hline \multirow[b]{2}{*}{ Explanatory variable } & \multicolumn{3}{|c|}{ Single-process model } & \multicolumn{3}{|c|}{$\begin{array}{l}\text { Multi-process model } \\
\text { with indicator of } \\
\text { being employed } \\
\text { (Model M2) }\end{array}$} & \multicolumn{3}{|c|}{$\begin{array}{l}\text { Multi-process model } \\
\text { with duration } \\
\text { dependence since } \\
\text { entry into } \\
\text { employment } \\
\text { (Model M3) }\end{array}$} \\
\hline & \multicolumn{2}{|c|}{ Coeff. } & \multirow[t]{2}{*}{ SE } & \multicolumn{2}{|c|}{ Coeff. } & \multirow[t]{2}{*}{ SE } & \multirow{2}{*}{\multicolumn{2}{|c|}{ Coeff. }} & \multirow[t]{2}{*}{ SE } \\
\hline Educational level (ref. = tertiary) & & & & & & & & & \\
\hline Secondary & 0.58 & $* * *$ & 0.06 & 0.57 & $* * *$ & 0.06 & 0.57 & $* * *$ & 0.06 \\
\hline Vocational & 0.91 & $* \star \star$ & 0.07 & 0.91 & *** & 0.07 & 0.91 & $* \star *$ & 0.07 \\
\hline Primary & 1.37 & *** & 0.10 & 1.37 & $\star \star \star *$ & 0.10 & 1.37 & $* \star *$ & 0.10 \\
\hline In education & 0.76 & *** & 0.06 & 0.76 & $\star \star \star *$ & 0.07 & 0.76 & $\star \star \star *$ & 0.07 \\
\hline \multicolumn{10}{|l|}{ Work experience $($ ref. $=$ none $)$} \\
\hline $0-3$ years (slope) & 0.03 & & 0.04 & 0.03 & & 0.04 & 0.03 & & 0.04 \\
\hline $3-6$ years (slope) & 0.05 & * & 0.03 & 0.05 & * & 0.03 & 0.05 & * & 0.03 \\
\hline $6-10$ years (slope) & 0.04 & $\star *$ & 0.02 & 0.05 & ** & 0.02 & 0.05 & ** & 0.02 \\
\hline 10 years or more (slope) & 0.03 & $* * *$ & 0.01 & 0.03 & $* * *$ & 0.01 & 0.03 & $* \star *$ & 0.01 \\
\hline
\end{tabular}


Vignoli et al.: The positive impact of women's employment on divorce: Context, selection, or anticipation? 